\title{
RESEARCH
}

Open Access

\section{Engineering Escherichia coli biofilm to increase contact surface for shikimate and L-malate production}

Qiang Ding ${ }^{1,2}$, Yadi Liu ${ }^{1,2}$, Guipeng Hu ${ }^{1,2}$, Liang Guo ${ }^{1,2}$, Cong Gao ${ }^{1,2}$, Xiulai Chen ${ }^{1,2}$, Wei Chen ${ }^{1,2}$, Jian Chen ${ }^{1,2}$ and Liming Liu ${ }^{1,2^{*}}$

\begin{abstract}
Microbial organelles are a promising model to promote cellular functions for the production of high-value chemicals. However, the concentrations of enzymes and nanoparticles are limited by the contact surface in single Escherichia coli cells. Herein, the definition of contact surface is to improve the amylase and CdS nanoparticles concentration for enhancing the substrate starch and cofactor NADH utilization. In this study, two biofilm-based strategies were developed to improve the contact surface for the production of shikimate and L-malate. First, the contact surface of E. coli was improved by amylase self-assembly with a blue light-inducible biofilm-based SpyTag/SpyCatcher system. This system increased the glucose concentration by $20.7 \%$ and the starch-based shikimate titer to $50.96 \mathrm{~g} \mathrm{~L}^{-1}$, which showed the highest titer with starch as substrate. Then, the contact surface of E. coli was improved using a biofilm-based CdS-biohybrid system by light-driven system, which improved the NADH concentration by $83.3 \%$ and increased the $\mathrm{NADH}$-dependent L-malate titer to $45.93 \mathrm{~g} \mathrm{~L}^{-1}$. Thus, the biofilm-based strategies can regulate cellular functions to increase the efficiency of microbial cell factories based on the optogenetics, light-driven, and metabolic engineering.
\end{abstract}

Keywords: Biofilm, Contact surface, Self-assembly, Biohybrid, Shikimate, L-malate

\footnotetext{
*Correspondence: mingll@jiangnan.edu.cn

1 State Key Laboratory of Food Science and Technology, Jiangnan

University, 1800 Lihu Road, Wuxi 214122, China

Full list of author information is available at the end of the article
}

\section{Springer Open}

(c) The Author(s) 2021. Open Access This article is licensed under a Creative Commons Attribution 4.0 International License, which permits use, sharing, adaptation, distribution and reproduction in any medium or format, as long as you give appropriate credit to the original author(s) and the source, provide a link to the Creative Commons licence, and indicate if changes were made. The images or other third party material in this article are included in the article's Creative Commons licence, unless indicated otherwise in a credit line to the material. If material is not included in the article's Creative Commons licence and your intended use is not permitted by statutory regulation or exceeds the permitted use, you will need to obtain permission directly from the copyright holder. To view a copy of this licence, visit http://creativecommons.org/licenses/by/4.0/. 


\section{Graphical Abstract}

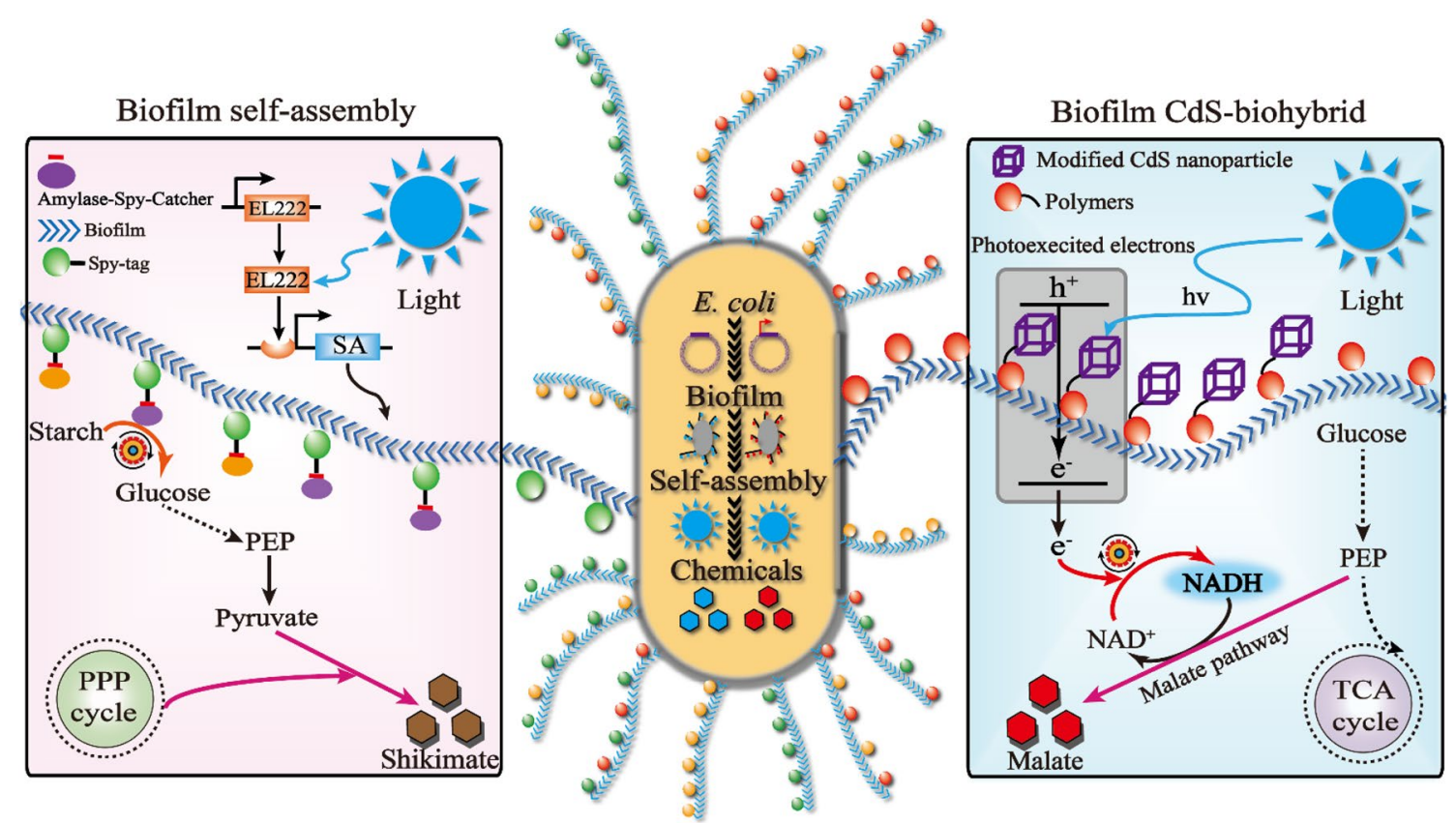

\section{Introduction}

Microbial cell factories can utilize reproducible substances in a promising, alternative, and environmentally friendly manner for the production of high-valuable and green chemicals, including food additives, advanced biofuels, and fine pharmaceuticals (Choi et al. 2019; Ko et al. 2020; Lee and Kim 2015; Nielsen and Keasling 2016). To improve the efficiency of microbial cell factories, various strategies at the DNA level (genome engineering and promoter engineering) (Choe et al. 2019; Ohta et al., 1991; Walker et al. 1999), RNA level (RNA ribozyme switch and transcription factor engineering) (Alper and Stephanopoulos 2007; Choi et al. 2019; Pham et al. 2017), protein level (protein engineering and cofactor engineering) (Li et al. 2020; Quijano-Rubio et al. 2021; Titorenko et al. 2002), metabolite level (scaffold engineering) (Niemeyer et al. 1994; Ellis et al. 2019), and cellular level (organelle engineering, morphology engineering, and consortium engineering) (Avalos et al. 2013; Ding et al. 2020; Honjo et al. 2019; Koizumi et al. 1998) have been developed. In particular, organelles could increase the efficiency of microbial cell factories at the cellular level by compartmentalizing key enzymes into targeted sub-organelles to improve enzymatic reaction efficiencies (Hammer and Avalos 2017).

To increase the enzymatic reaction efficiency by using sub-organelles, various strategies have been utilized, including extracellular organelles, in which transport proteins regulate the movement of substances across the cell wall by rewiring functional membrane microdomains or vesicles (Dueber et al. 2009; Sandoval and Papoutsakis 2016; Yang et al. 2021); intracellular organelles, including mitochondria, peroxisomes, and endoplasmic reticulum, to improve intermediate product concentrations and accelerate enzymatic reactions (Avalos et al. 2013) (DeLoache et al. 2016; Grewal et al. 2020); and artificial organelles, such as phase-separated droplets engineered to increase the transformation efficiency by concentrating key pathway enzymes into a compartment (Castellana et al. 2014; Kuska and O’Reilly 2020; Zhao et al. 2019). However, few studies have focused on the contact surface as a physiological parameter of extracellular organelles and a key determinant of the efficiency of microbial cell factories (Nguyen et al. 2014; Sakimoto and Yang 2016; Zhang et al. 2018). Biofilms, as an extracellular organelle, can form on the cell surface to promote the self-assembly of enzymes or nanoparticles for increased substrate utilization (Jiang et al. 2018; Nguyen et al. 2014; Olmez et al. 2019; Wei et al. 2018). Chemical biosynthesis by Escherichia coli, Pseudomonas putida, or Bacillus subtilis could be effectively improved by using biofilms to regulate the contact surface, thereby improving the enzymatic reaction efficiency and chemical production (Benedetti et al. 2016; Leonov et al. 2021; Nguyen et al. 2014).

Biofilms are important microbial organelles that can be regulated by biofilm formation genes, e.g., the curli 
nanofiber genes, including the biofilm structure gene $\operatorname{csg} A$, nucleation gene $\operatorname{csg} B$, processing genes $\operatorname{csg} E$ and $\operatorname{csg} F$, secretion genes $\operatorname{csg} C$ and $\operatorname{csg} G$, and direct transcriptional regulatory gene $\operatorname{csg} D$ to form bacterial biofilms (Kay et al. 2006; Nguyen et al. 2014) and biofilm regulatory genes, including the secondary messenger c-di-GMP, quorum sensing relative signal molecules, and the two component system involved in cellular physiological metabolism (Valentini and Filloux 2016; Yarwood et al. 2004). Moreover, surface biofilms can have multiple functions: improving stress tolerance by forming a protective barrier against changes in the complex environment (Gilbert and Ellis 2019); enhancing biochemical production, which can accelerate bioconversion rates via the immobilized microbial community (Alvarez-Ordóez et al. 2019); improving chemical production via an increased cell density in biofilm-mediated microbial fermentation (Ercan and Demirci 2013); and achieving continuous fermentation by utilizing long-term physical robustness (Cuny et al. 2019; Jiang et al. 2021). These properties are beneficial for the application of biofilms in the microbial biochemical production process. For example, functional peptides (e.g., FLAG, CLP12, and Mms6) fused to the E. coli biofilm protein CsgA have been used to construct a biofilm-integrated nanofiber display strategy for improved tolerance and substrate adhesion (Nguyen et al. 2014). P. putida biofilms can be activated and degraded via $y e d Q$ and $y h j H$ to degrade haloalkanes (Benedetti et al. 2016). The B. subtilis biofilm protein TasA has been assembled into TasA-OPH and TasA-HisTag nanofibers to achieve a two cascade enzyme reaction for transforming PAR to PAP, integrating Ni-NTA-decorated gold nanoparticles (Huang et al. 2019). Therefore, biofilms can be incorporated into self-assembly or biohybrid systems to increase the contract surface and thereby improve enzymatic reaction efficiencies.

In this study, the definition of contact surface is mainly to reinforce the amylase and CdS nanoparticles titer for enhancing the shikimate and L-malate synthesis. Thus, the $E$. coli biofilms were used to form a self-assembly system or CdS-biohybrid system to improve the contact surface for shikimate and L-malate production. First, the optogenetics system was used to control the biofilmbased SpyTag/SpyCatcher system to improve the amylase and glucose concentration for shikimate production. Second, the light-driven system was utilized to regulate the biofilm-based CdS-biohybrid system to improve CdS nanoparticles and NADH concentration for L-malate production. These biofilm-based strategies are promising approaches to increase chemical production by metabolic engineering.

\section{Materials and methods}

\section{Strains and culture conditions}

All plasmids and bacterial strains used in this study are listed in Additional file 1: Tables. Luria-Bertani (LB) broth and Terrific broth (TB) plates were used for choosing a strain. Kanamycin $\left(50 \mathrm{mg} \mathrm{L}^{-1}\right)$, ampicillin (100 $\left.\mathrm{mg} \mathrm{L}^{-1}\right)$, spectinomycin $\left(30 \mathrm{mg} \mathrm{L}^{-1}\right)$, and IPTG $(500 \mu \mathrm{M})$ were added appropriately according to different conditions.

For shikimate production, seed cultures were used for fermentation by transferring fresh colonies to a $50 \mathrm{~mL}$ shake flask containing $30 \mathrm{~mL} \mathrm{LB}$ medium. After culturing for $12 \mathrm{~h}$ at $37^{\circ} \mathrm{C}$ and $200 \mathrm{rpm}$, this fermentation solution was inoculated into a $250 \mathrm{~mL}$ flask with $50 \mathrm{~mL}$ fermentation medium $\left(10 \mathrm{~g} \mathrm{~L}^{-1}\right.$ casamino acids, $\mathrm{K}_{2} \mathrm{HPO}_{4}\left(7.5 \mathrm{~g} \mathrm{~L}^{-1}\right)$, iron ammonium (III) citric acid $\left(0.3 \mathrm{~g} \mathrm{~L}^{-1}\right)$, citric acid monohydrate $\left(2.1 \mathrm{~g} \mathrm{~L}^{-1}\right)$, L-phenylalanine $\left(0.7 \mathrm{~g} \mathrm{~L}^{-1}\right)$, L-tyrosine $\left(0.7 \mathrm{~g} \mathrm{~L}^{-1}\right)$, L-tryptophan $\left(0.35 \mathrm{~g} \mathrm{~L}^{-1}\right)$, and concentrated $\mathrm{H}_{2} \mathrm{SO}_{4}(1.2 \mathrm{~mL})$, adding trace elements and amino acids according to this reference (Knop et al. 2001)) with an initial optical density at $600 \mathrm{~nm}\left(\mathrm{OD}_{600}\right)$ of 0.1 , and then $10 \mathrm{~g} \mathrm{~L}^{-1} \mathrm{CaCO}_{3}$ was added as an acid neutralizing agent. For fed-batch cultures in a $3.6 \mathrm{~L}$ fermenter, seed cultures were used for fermentation by transferring fresh colonies to a $250 \mathrm{~mL}$ flask containing $50 \mathrm{~mL} \mathrm{LB}$ medium. Shikimate fermentation was carried out in a $3.6 \mathrm{~L}$ fermenter containing $1.5 \mathrm{~L}$ fermentation medium with $10 \%$ inoculum size and $10 \% \mathrm{w} / \mathrm{v}$ starch. Shikimate fermentation was maintained at $\mathrm{pH} 6.0$, rotate rate $650 \mathrm{rpm}$, air flow 1 vvm, and $37^{\circ} \mathrm{C}$ by the automatic addition of $4 \mathrm{M} \mathrm{NaOH}$ or $2 \mathrm{M} \mathrm{HCl}$.

For L-malate production, seed cultures were used for fermentation by transferring fresh colonies to a $50 \mathrm{~mL}$ shake flask containing $30 \mathrm{~mL}$ LB medium $\left(10 \mathrm{~g} \mathrm{~L}^{-1}\right.$ casamino acids). After culturing for $12-18 \mathrm{~h}$ at $37{ }^{\circ} \mathrm{C}$ and $200 \mathrm{rpm}$, this fermentation solution was inoculated into a $35 \mathrm{~mL}$ flask with $20 \mathrm{~mL}$ NBS medium to anaerobic fermentation with $\mathrm{OD}=10$ (adding $60 \mathrm{~g} \mathrm{~L}^{-1}$ glucose,). And then to $100 \mathrm{~g} / \mathrm{L} \mathrm{NaHCO}_{3}$ maintain the solution $\mathrm{pH}=7$ and releasing redundant carbon dioxide gas for every $12-24 \mathrm{~h}$, respectively. For fed-batch cultures in a $3.6 \mathrm{~L}$ fermenter, seed cultures were used for fermentation by transferring fresh colonies to a $250 \mathrm{~mL}$ flask containing $50 \mathrm{~mL} \mathrm{LB}$ medium. L-malate fermentation was carried out in a $3.6 \mathrm{~L}$ fermenter containing $1.5 \mathrm{~L}$ fermentation medium and $60 \mathrm{~g} \mathrm{~L}^{-1}$ initial glucose, and then supplied with $800 \mathrm{~g} \mathrm{~L}^{-1}$ glucose at $36 \mathrm{~h}$. L-malate fermentation condition was maintained at $\mathrm{pH} 6.5$, rotate rate $100-200 \mathrm{rpm}$ for anaerobic condition, and $37{ }^{\circ} \mathrm{C}$ by the automatic addition of $100 \mathrm{~g} / \mathrm{L}$ $\mathrm{NaHCO}_{3}$. 


\section{DNA manipulation and plasmid construction}

Gene deletions were performed according to the Red homologous recombination method. All plasmids were constructed using basic molecular cloning techniques and Gibson assembly. To construct the shikimate biosynthesis pathway, it used the previous strain. For constructing the L-malate biosynthesis pathway, the strain is the previous reported. The el222 gene was constructed by Suzhou Genewiz Biotechnology with codon optimization (Jayaraman et al. 2016, 2018). Primers used in this study are listed in Additional file 1: Tables.

\section{Light culture condition}

The optogenetics illumination for gene expression and fermentation were carried out with blue light LED panel (MODEL: HF-FX160, square light source), which placed $4 \mathrm{~cm}$ from cell culture. The light intensity can be regulated by switching power supply with a controller. The applicability of scale fermentation can be improved through utilizing a wrap-round illumination way to increasing the light penetration with two or three blue light sources to surround $3.6 \mathrm{~L}$ fermenter.

According to light-driven experiments, the blue light was used to activate the electronics generation for NADH regeneration, which placed $4 \mathrm{~cm}$ far from shake flask. The process of biohybrid system assembly can be learned from. E. coli cells containing biohybrid CdS or InP nanoparticles were harvested from LB medium by centrifugation (4000 rpm for $10 \mathrm{~min}$ ). The reaction was initiated by blue light irradiation and stopped by centrifugation and separation of E. coli-CdS nanoparticles or $E$. coli-InP nanoparticles (Guo et al., 2018; Jin et al. 2021; Wei et al. 2018).

Total NADH content, NADH content, and $\mathrm{NAD}^{+}$content of fermentation solution were detected and followed by Biyuntian Cofactor Determination Kit.

\section{Biofilm formation, congo staining, and alcian-congo staining}

The cells were then streaked or spotted onto YESCA medium, containing $10 \mathrm{~g} \mathrm{~L}^{-1}$ of casamino acids, $1 \mathrm{~g} \mathrm{~L}^{-1}$ of yeast extract, or seed cultures were inoculated from glycerol stocks and grown in LB Miller medium for $12 \mathrm{~h}$ at $37^{\circ} \mathrm{C}$. Experimental cultures were grown at $30^{\circ} \mathrm{C}$ and $180 \mathrm{rpm}$ in M63 minimal medium supplemented with $1 \mathrm{mM} \mathrm{MgSO} 4$ and with $0.2 \% \mathrm{w} / \mathrm{v}$ glucose or $0.2 \% \mathrm{w} / \mathrm{v}$ glycerol (Huang et al. 2019; Nguyen et al. 2014).

For congo red (CR) staining, the stains were grown in YESCA or M63 minimal medium for $12 \mathrm{~h}$ at $30{ }^{\circ} \mathrm{C}$ and $180 \mathrm{rpm}$. Subsequently, $10 \mu \mathrm{L}$ cultures were spotted onto YESCA- or M63-CR plates, supplemented with $25 \mu \mathrm{g} /$ $\mathrm{mL}$ of $\mathrm{CR}$ and $5 \mu \mathrm{g} / \mathrm{mL}$ of Brilliant Blue G250. The plates were then imaged to determine the extent of CR binding after $48 \mathrm{~h}$ of incubation at $30^{\circ} \mathrm{C}$. Curli-producing bacteria form red colonies, whereas non-producing cells form white colonies.

For alcian-congo staining, the culture conditions of strains were similar to congo staining. Alcian Blue (AB) Dye: $2 \mathrm{~g}$ Alcian blue, $3 \mathrm{~mL}$ glacial acetic acid, $97 \mathrm{~mL}$ distilled water; (2) Congo red dye: Congo red $2 \mathrm{~g}$, distilled water $100 \mathrm{~mL}$ Congo red-alcian blue staining method: a little normal saline was dropped on a clean slide; the bacteria were picked up and mixed them with the inoculation needle. Then, it was added to the same amount of $\mathrm{AB}$ dye with normal saline, and it was mixed well and let stand for 3-5 min. Finally, a little congo red dye was added to dye cell, and then the results can be observed from the oil mirror under the fluorescence microscopy.

\section{BLRS implementation}

Blue light repression system (BLRS) was constructed. Additional file 1: Data S1-S3 showed the names and sequences of BLAS. In BLAS, two plasmids, $\mathrm{P}_{\text {Tac }}$-EL222 and PJ-mKate, were used as input plasmids with various blue light illuminations.

To test BLRS, a colony of BLRS cells containing $\mathrm{P}_{\text {Tac }}$-EL222 and PJ-mKate was inoculated into medium with the corresponding ampicillin and spectinomycin for overnight $(12 \sim 14 \mathrm{~h})$ at $37^{\circ} \mathrm{C}$. Then, seed cultures were inoculated in the refresh LB for $12 \sim 14 \mathrm{~h}$ under the different blue light $(450 \mathrm{~nm}$ ) illuminations. This experiment was repeated with a different starting colony for three biological replicates. All cultures were grown in $50 \mathrm{~mL}$ medium in $250 \mathrm{~mL}$ shake flasks at $200 \mathrm{rpm}$. Finally, fluorescence density was analyzed (see below).

\section{Analytical methods}

The $\mathrm{OD}_{600}$ was measured using a spectrophotometer. Glucose analysis was quantified by the biosensor SBA$90 \mathrm{E}$ biological sensor. Shikimate was determined by highperformance liquid chromatography using an Aminex HPX-87H column $(7.8 \times 300 \mathrm{~mm}$; Bio-Rad Laboratories, Inc., Hercules, CA, USA) at $60{ }^{\circ} \mathrm{C}$ with $0.05 \mathrm{mM}$ sulfuric acid as the mobile phase. The injection volume was $20 \mu \mathrm{L}$, and the flow rate was $0.6 \mathrm{~mL} \mathrm{~min}^{-1}$. L-malate was determined by high sulfuric acid as the mobile performance liquid chromatography using the same column at $45^{\circ} \mathrm{C}$ with $0.05 \mathrm{mmol}^{-1}$ phase. Bacterial cells were harvested by centrifugation at $8000 \mathrm{r} \mathrm{min}{ }^{-1}$ for $10 \mathrm{~min}$. The supernatant was discarded, and then cells were washed twice with $20 \mathrm{~mL}$ distilled water.

\section{ICP-MS and XPS assay}

For XPS assay, the specific operation is to grind the sample into fine powder, and it was spread on the aluminum foil. Then, it was covered into a piece of aluminum foil 
and flattened through hydraulic press. Finally, it was cut into a certain shape with scissors and wait for the test.

For ICP-MS, the samples need to do the digestion, all organic substances are completely digested as far as possible, and the solid and liquid samples are converted into stable and clarified acidic aqueous solution (2\% nitric acid $\mathrm{v} / \mathrm{v}$ ), without sol and precipitation. In order to prevent the clogging of the capillary atomizer tube, a microporous filter membrane of $0.22 / 0.45 \mathrm{um}$ is needed (Wei et al. 2018).

\section{Flow cytometer assays}

For flow cytometer analysis, E. coli cells were washed twice with PBS, and then resuspended to an $\mathrm{OD}_{600}$ of 0.2. The assays were performed by a LSR Fortessa instrument using PE-TxRed (mKate) and GFP channels. The voltage gains for each detector were set to PE-TxRed, $650 \mathrm{~V}$ or FITC, and $407 \mathrm{~V}$. Compensation was performed using cells without mKate or GFP. For each sample, at least 20,000 counts were recorded using a $0.5 \mathrm{~mL} \mathrm{~s}^{-1}$ flow rate. A gate was previously designed based on forward and side scatter ( $>99 \%$ cells were chosen for the analysis of fluorescence density percentage).

\section{Assay of qPCR measurements}

Measurement of the mRNA level of mKate was based detected by qPCR. Primers were used for amplifying the DNA region proximal to the mKate. The qPCR reactions were performed with a SuperReal Premix SYBR Green Plus kit according to its manual. For each PCR reaction, 15-20 $\mu \mathrm{L}$ sample contained 10-15 ng of DNA, $0.6 \mu \mathrm{M}$ of each primer, and $10 \mu \mathrm{L}$ of $2 \times$ SYBR Green Supermix. The reaction process was carried out in an Opticon 2 Real-time PCR system based on the directions: $95^{\circ} \mathrm{C}$ for $3 \mathrm{~min}$, followed by 40 cycles of $95{ }^{\circ} \mathrm{C}$ for $30 \mathrm{~s}, 60{ }^{\circ} \mathrm{C}$ for $30 \mathrm{~s}$, and $72{ }^{\circ} \mathrm{C}$ for $30 \mathrm{~s}$. The qPCR product was checked in a 1.5-2\% agarose gel to ensure the efficiency of PCR amplification. The $16 \mathrm{~S}$ rRNA was used as the reference gene to normalize the expression level of targeted gene. For each RNA preparation, at least three independent real-time PCR measurements were performed, respectively. RT-PCR primers are listed in Additional file 1: Tables.

\section{The bioimage of agarose plates}

$E$. coli strains, including BLRS systems, were cultured overnight, respectively. A photomask was placed on the bottom side of the prepared agar plate and used aluminum oxide to avoid blue light illumination. Seed cultures were transferred to fresh medium for $\mathrm{OD}_{600}=0.5-0.8$, and then $400-600 \mu \mathrm{L}$ bacteria cultures were taken to plate for bioimaging assay. The whole setup was kept inside the incubator at $37^{\circ} \mathrm{C}$. The LB plates were illuminated under $450 \mathrm{~nm}$ blue light or dark condition for $36-48 \mathrm{~h}$.

\section{Cell viability assays}

The viability of cells in LB plates were assessed by inoculating cells in fermentation medium. Cells were diluted to $\mathrm{OD}_{600}=0.5$ and $10 \mu \mathrm{L}$ of $10 \times$ serially diluted cell suspension was spread on each agar plate with different strains. Then, the LB plates were cultured with $37{ }^{\circ} \mathrm{C}$ for $12 \mathrm{~h}$. Next, the numbers of living cell in different culture times and different strains were calculated, respectively.

\section{Enzymatic assays}

As for amylase assay, after $12 \mathrm{~h}$ of growth, each sample was collected from cultures via centrifugation at $4{ }^{\circ} \mathrm{C}$ for $15 \mathrm{~min}$, and the $200 \mu \mathrm{L}$ enzyme solution was taken into solution. Enzymatic activity of $\alpha$-amylase was quantitatively determined based on the 3,5-dinitrosalicylic acid method by using $200 \mu \mathrm{L}$ reaction mixture containing 0.5 wt\% soluble starch in $20 \mathrm{mM}$ sodium acetate buffer and $50 \mu \mathrm{L}$ enzyme solution at $\mathrm{pH}=5.5$. The $\mathrm{pH}$ of the reaction mixture was controlled by using $5 \mathrm{M} \mathrm{NaOH}$ solution. Enzymatic reactions were terminated by adding a solution consisting of $0.4 \mathrm{M} \mathrm{NaOH}, 22 \mathrm{mM} \mathrm{3,5-dinitro-}$ salicylic acid, and 1.1 M potassium sodium (+)-tartrate tetrahydrate incubated for $5 \mathrm{~min}$. And then the DNS method was used to detect the enzyme activity.

\section{Assay of congo red degradation}

InP and CdS nanoparticles were purchased from Aladdin web. $60 \mathrm{mg} / \mathrm{L}$ congo red solution was cultured with $E$. coli and nanoparticles during the $450 \mathrm{~nm}$ blue light culture. After culturing $90 \mathrm{~min}$, the sample was collected to detect the congo red degradation in the $540 \mathrm{~nm}$ by using a SpectraMax M3 plate reader.

\section{Assay of fluorescence intensity}

The engineered $E$. coli strains used for assaying fluorescence intensity were plated on the LB plates for overnight at $37{ }^{\circ} \mathrm{C}, 200 \mathrm{rpm}$. After that, they were inoculated into $50 \mathrm{~mL}$ fresh LB with $1-2 \%$ inoculum size (vol/vol) and then cultured at $37^{\circ} \mathrm{C}, 200 \mathrm{rpm}$ for $12-16 \mathrm{~h}$. For assaying fluorescence intensity, the fluorescence of cell culture was detected by a SpectraMax M3 plate reader. The excitation and emission wavelengths of mKate gene was set at $588 \pm 10 \mathrm{~nm}$ and $645 \pm 10 \mathrm{~nm}$, respectively.

\section{Results}

Screening of $E$. coli biofilm genes

To obtain an available and controllable biofilm system, the five genes involved in E. coli biofilm formation were screened to obtain the biofilm. As illustrated in Fig. 1, $\operatorname{csg} A, \operatorname{csg} B, \operatorname{csg} C, \operatorname{csg} D$, and $\operatorname{csg} E$ were each overexpressed 




D

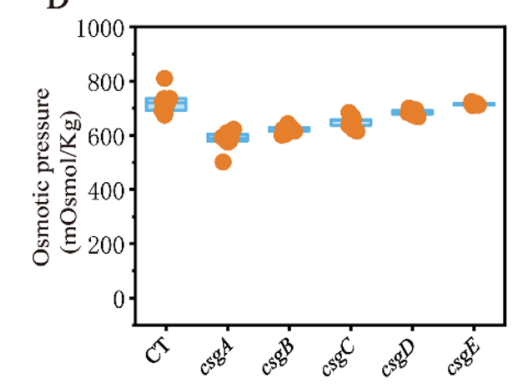

G
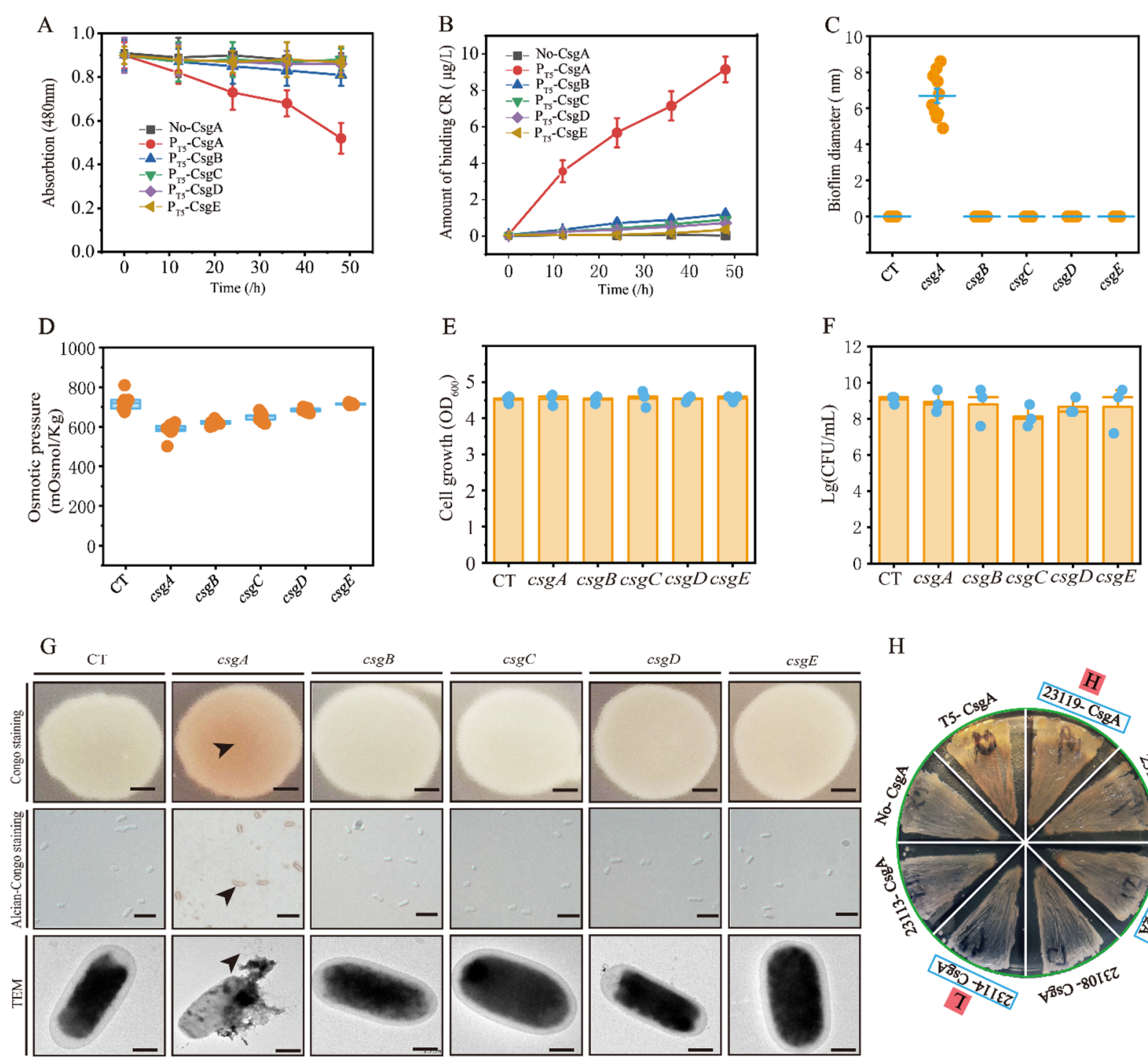

E

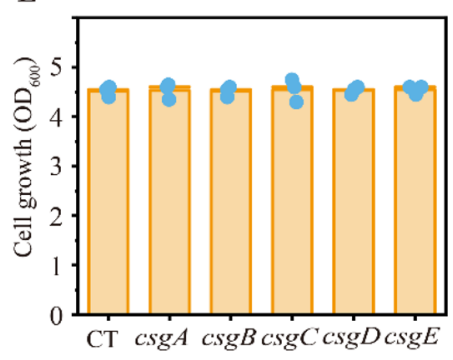

$\mathrm{F}$

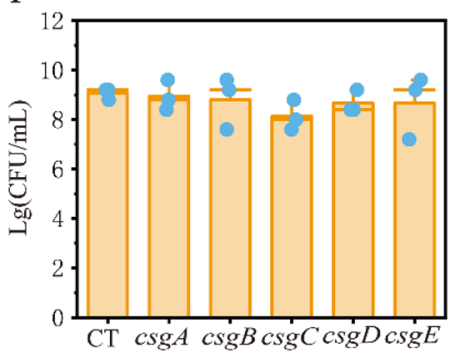

Fig. 1 Characterization of E. coli biofilm synthesis by genetic manipulation. A The absorption of congo red with different biofilm genes in E. coli MG1655. B Comparing the amount of binding congo red with different biofilm genes in E. coli 1655. C Comparing the biofilm diameter with different biofilm genes in E. coli MG1655. D The osmotic pressure with different biofilm genes in E. coli MG1655. E The changes of CFU with different biofilm genes in E. coli MG1655. F The changes of cell growth with different biofilm genes in E. coli 1655. G Comparing the congo red staining, alcian-congo staining, and TEM with different biofilm genes in E. coli MG1655. $\mathbf{H}$ Comparing the different promoters to control biofilm csgA expression in E. coli 1655, " $\mathrm{H}$ " is high strength, " $\mathrm{M}$ " is medium strength, "L" is low strength. For $\mathrm{A}-\mathrm{D}, n=3$. Error bars, mean \pm s.d. Scale bar for congo staining is $1 \mathrm{~cm}$, Scale bar for congo staining is $2 \mathrm{~mm}$, Scale bar for Alcian-Congo staining is $5 \mu \mathrm{m}$, Scale bar for TEM is $1 \mu \mathrm{m}$

in E. coli MG1655 to induce biofilm formation. An obvious difference was observed in the engineered strains overexpressing $\operatorname{csg} A$. The standard amyloid-staining colorimetric dye Congo red was used to determine the extent of biofilm production through strongly binding the curli nanofiber (Jiang et al. 2018; Nguyen et al. 2014). Thus, the absorption peak of Congo red and osmotic pressure was $43.47 \%$ and $20.46 \%$ lower in the engineered strains overexpressing $\operatorname{csg} A$ than in the control strain, respectively (Fig. 1A, D). Furthermore, the amount of bound Congo red and biofilm diameter for the engineered strain overexpressing $\operatorname{csg} A$ increased to $9.21 \mathrm{ng}$ and $6.7 \mathrm{~nm}$, respectively (Fig. 1B, C). However, the cell growth $\left(\mathrm{OD}_{600}\right)$ and colony-forming unit (CFU) of E. coli was not changed significantly (Fig. 1E, F). The biofilm was represented and identified by Congo red staining, alcian-congo red staining, and transmission electricity microscopy (TEM) (Fig. 1G). 
To confirm the controllability of E. coli biofilm formation, $\operatorname{csg} A$ was controlled by promoters with different strengths, resulting in differences in the amount of bound Congo red. Thus, this demonstrates that the positive relations between the amount of bound Congo red with stronger biofilm expression (Fig. 1H). These results demonstrate that $\operatorname{csg} A$ is an efficient and controllable target to increase the contact surface for Congo red absorption.

\section{Increasing the contact surface by biofilm self-assembly and CdS-biohybrid systems}

After validating the effect of the $E$. coli biofilm gene $\operatorname{csg} A$, two distinct groups were established. In the first group, the biofilm gene was overexpressed and a split-adhesion system was used, in which a 13-amino-acid peptide (SpyTag) forms a highly specific and spontaneous isopeptide bond with a $15 \mathrm{kDa}$ protein (SpyCatcher) to construct a biofilm-based self-assembly system. In the second group, the surface of the E. coli biofilm and CdS nanoparticles was modified by polyphenol functionalization, resulting in programmed adhesion to $\mathrm{CdS}$ nanoparticles to construct a CdS-biohybrid system.

A biofilm-based SpyTag/SpyCatcher self-assembly system was developed to improve the contact surface for heterogeneous proteins (Fig. 2A). To demonstrate that the SpyTag/SpyCatcher system can assemble with the biofilm on the cell surface, the CsgA-SpyTag fused protein and GFP-SpyCatcher fused protein were overexpressed and secreted to form the biofilm self-assembly system for GFP protein expression on the cell surface. The following results were obtained: (i) SDS-PAGE and TEM demonstrated the expression and extracellular secretion of this biofilm self-assembly system (Fig. 2B, C); (ii) fluorescence microscopy observations showed GFP expression on the E. coli surface (Fig. 2D); and (iii) the absorbance of Congo red decreased to 0.54 after biofilm self-assembly (Fig. 2E). Based on these results, the biofilm-based SpyTag/SpyCatcher protein self-assembly system can improve the contact surface by fixing the heterogeneous proteins on the extracellular biofilm.

Another biofilm-based CdS-biohybrid system was constructed to increase the contact surface for CdS nanoparticles (Fig. 2F and Additional file 1: Figure S1). Two typical light-harvesting nanoparticles, InP and CdS, and E. coli biofilm CsgA were modified using the polyphenol-based method (Guo et al., 2018). The nanoparticles were functionalized to attach to E. coli CsgA for display on the cell surface (Fig. 2G and Additional file 1: Figure S1). We obtained the following key results. (i) The CdS and InP nanoparticles were efficiently attached to the extracellular biofilm, as determined using TEM (Fig. 2G). (ii) The qualitative elemental composition of $\mathrm{CdS}$ and InP nanoparticles in the biofilm-based biohybrid system levels were $1.44,1.65,1.28$, and $0.21 \%$ of $\mathrm{S}, \mathrm{Cd}$, In, and $\mathrm{P}$, respectively, as determined using XPS (Fig. 2H, I). (iii) A quantitative elemental composition analysis of $\mathrm{CdS}$ and InP nanoparticles in the biofilm-based biohybrid system showed improvements to 53.64, 112.07, 15.58, and $19.26 \%$ of Cd, S, In, and P, respectively, using ICPMS, demonstrating that the CdS nanoparticles exhibited a high biofilm attachment capacity (Fig. 2J). Based on the above results, the CdS nanoparticle was effective for forming the biofilm-based CdS-biohybrid system. These results confirmed that the biofilm-based CdS-biohybrid system can improve the contact surface through reinforce the CdS nanoparticle titer on the biofilm.

\section{Reinforcing shikimate production via increased amylase and glucose concentrations with an improved contact surface}

An engineered E. coli $\mathrm{S} 1$ was constructed, in which the $\operatorname{aro} B$, aro $G$, and $t k t A$ genes involved in the shikimate synthesis pathway were overexpressed and amylase concentration was increased (Fig. 3A). Then, starch utilization by the engineered $E$. coli $\mathrm{S} 1$ was analyzed. (1) The color ring of E. coli $\mathrm{S} 1$ was $68.35 \%$ larger than that of the wild type (Fig. 3B). (2) The enzyme index, amylase concentration, and glucose concentration of $E$. coli S1 were 0.7, $3.5 \mathrm{U}$, and $45 \mathrm{~g} \mathrm{~L}^{-1}$, respectively (Fig. 3C, Additional file 1: Figure S2). (3) Shikimate titer and productivity of E. coli $\mathrm{S} 1$ were $10.24 \mathrm{~g} \mathrm{~L}^{-1}$ and $0.14 \mathrm{~g} \mathrm{~L}^{-1} \mathrm{~h}^{-1}$, respectively (Fig. 3C). These results showed that a low glucose concentration may limit shikimate production, and this was associated with a low amylase concentration. To resolve the low glucose concentration during shikimate fermentation, the process of shikimate biosynthesis was divided into two modes: (i) starch utilization, which was increased by the self-assembling biofilm with inducible promoters (Fig. 3D) and (ii) shikimate production, in which pathway enzymes were induced by the blue lightregulated expression system (Fig. 3E).

To spatiotemporally control these two modes, a blue light repression system (BLRS) was constructed. As described in previous studies (Jayaraman et al. 2016, 2018), the EL222 light-sensitive protein was controlled by the Ptac promoter, and the central position of the -35 to -10 region of the $\mathbf{2 3 1 1 0}$ promoter was replaced with an EL222 binding site, which was then assembled into low copy $\mathrm{P}_{\mathrm{SC} 101}$ and $\mathrm{P}_{\text {cole }}$ to reduce the metabolic burden (Fig. 3F). Degradation tags of three strengths were used to regulate EL222 expression, and the DAS tag showed the best switch performance (Additional file 1: Figure S3). First, the abundance of mKate was 9.1-fold lower in response to blue light than in dark conditions and showed the homogeneity of this system based on flow cytometer (Fig. 4A-C). Next, SDS-PAGE and RT-PCR 

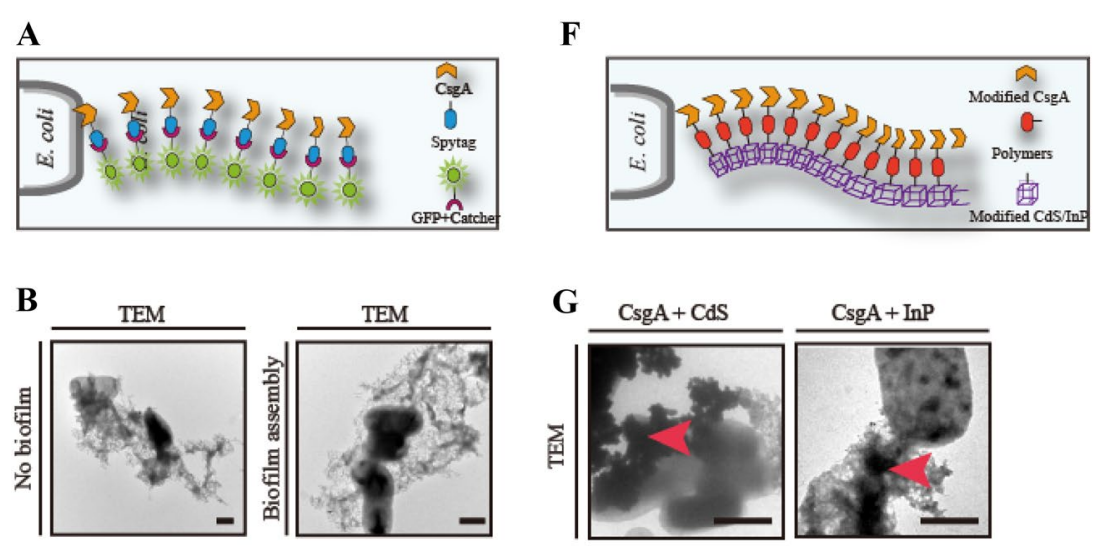

CT
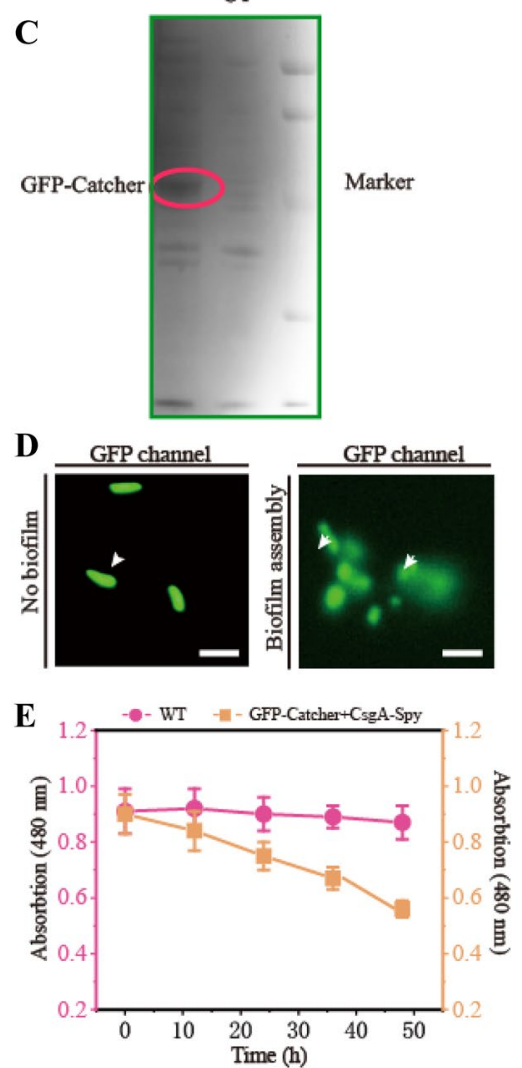

$\mathbf{H}$
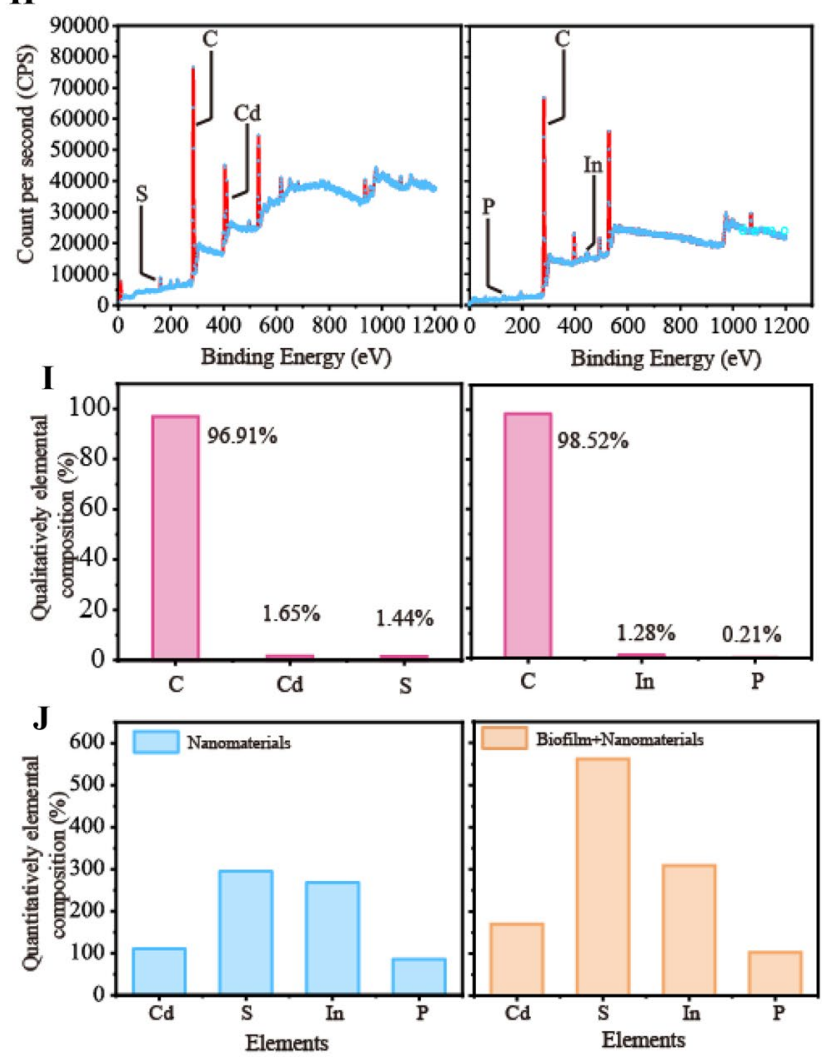

Fig. 2 Self-assembly of covalent immobilization proteins and nanoparticles based on biofilms. A The schematic diagram of self-assembly of Spy-Tag with GFP-catcher in E. coli MG1655. B The TEM exhibition in different E. coli MG1655. C The SDS-page exhibition in different E. coli MG1655. D Comparing the changes of assembly and no-assembly biofilm, expression and no-expression system by fluorescence detection. $\mathbf{E}$ The changes of absorption with or without biofilm. F The schematic diagram of self-assembly of nanoparticles with E. coli. G Comparing the TEM with InP or CdS in E. coli MG1655 biofilm. H, I The confirmation and atom account of randomly chosen biohybrids through XPS analysis. J Detecting concentration of $\mathrm{Cd}, \mathrm{S}, \mathrm{In}$, and P in different E. coli through ICP-MS. For C, $n=3$. Error bars, mean \pm s.d. Scale bar for $\mathbf{B}, \mathbf{G}$ is $1 \mu \mathrm{m}$, scale bar for (D) is $5 \mu \mathrm{m}$,

were performed to evaluate changes in mKate expression at the protein and transcript levels (Additional file 1: Figures S4 and S5). Then, bioimaging for "JNU" and "SynBio" was performed to display the spatial specificity of BLRS (Fig. 4D). In addition, the different strains, mediums, and light sources were used to show the university and specificity of BLRS (Additional file 1: Figures S5-S7). Furthermore, the optogenetics tool can efficiently regulate heterogeneous and endogenous bacterial genes; the galactosidase, the cell division proteins SulA and FtsZA, and cell lysis gene were chosen to exhibit the changes of the galactosidase activity, cell length, and cell lysis in 


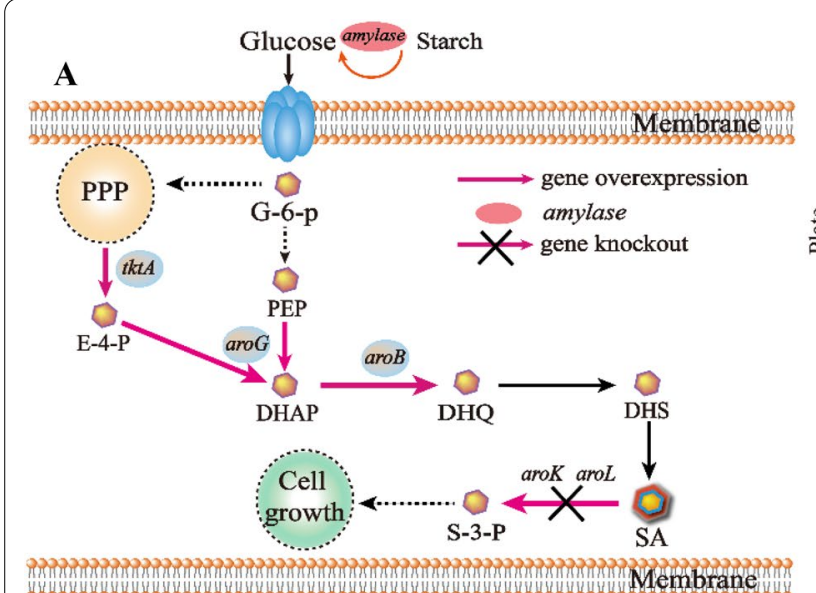

B

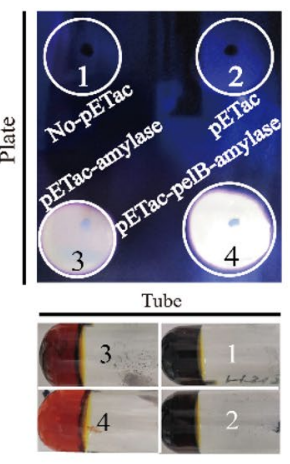

C

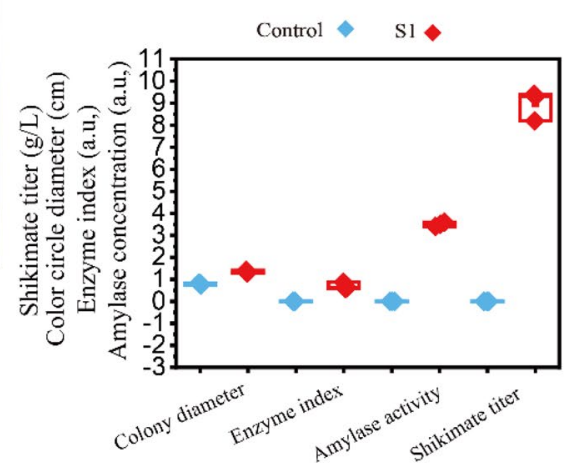



$\mathbf{F}$

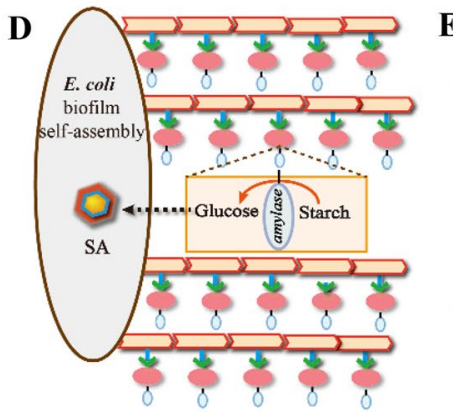

$\mathbf{E}$

(i) Starch utilization mode Inducible promoter $\rightarrow$ Assembly for amylase

(ii) Shikimate production mode

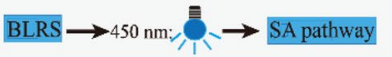

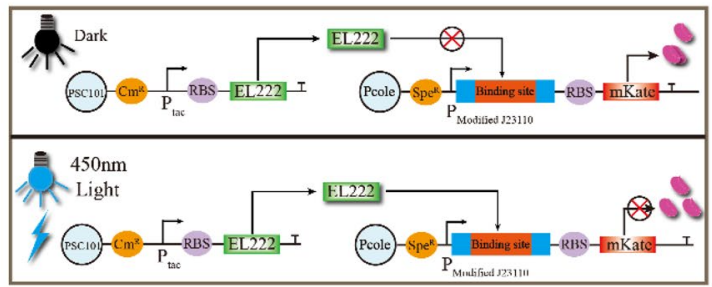

Fig. 3 Engineering shikimate synthesis by biofilm self-assembly. A The schematic diagram of shikimate biosynthesis pathway in E. coli S1. B Comparing the color circle with starch in different E. coli. C The changes of color circle diameter, enzyme index, amylase concentration, and shikimate titer in different E. coli. D Conceptual graph of starch utilization with biofilm-based SpyTag/SpyCatcher covalently protein system for L-malate production. E Conceptual graph of two modes fermentation for shikimate production. F The schematic diagram of BLRS, containing the plasmid Ptac-EL222 and PJ-mKate. For C, $n=3$. Error bars, mean \pm s.d. Each gene encodes the following: Glu: glucose; G6P: glucose-6-phosphate; PYR: pyruvate; PEP: phosphoenolpyruvate; AcCoA: acetyl-CoA; E4P, erythrose-4-phosphate; DAHP, 3-deoxy-D-arabino-heptulosonate-7-phosphate; Ru5P, Ribulose 5-phosphate; DHQ, 3-dehydroquinic acid; DHS, 3-dehydroshikimate; SA, shikimate

different blue light conditions (Additional file 1: Figures S8-S10). Finally, the BLRS system was scaled up to $5 \mathrm{~L}$ fermenter to show the applicability of optogenetics (Fig. 4E, F). Together, the results demonstrated that BLRS is effective for the regulation of gene expression.

Then, the biofilm-based SpyTag/SpyCatcher system was introduced into E. coli S1 to increase the contact surface, leading to improvements in the amylase and glucose concentrations for shikimate production via BLRS regulation. This biofilm self-assembly system was controlled by the Ptrc and PT5 promoters. The two modes were established by manipulating the timing of blue light illumination and inducer, respectively (Fig. 4E). This led to the formation of E. coli S6. As a result, the amylase and glucose concentrations in E. coli S6 under light conditions were $48.57 \%$ and $20.07 \%$ greater than those of E. coli S6 under dark conditions, respectively (Fig. 4G, Additional file 1: Figure S1). This led to increases in the starch-based shikimate titer and E. coli $\mathrm{S} 6$ productivity under light conditions to $15.04 \mathrm{~g} \mathrm{~L}^{-1}$ and $0.21 \mathrm{~g} \mathrm{~L}^{-1} \mathrm{~h}^{-1}$, which were $46.88 \%$ and $46.88 \%$ greater than those of $E$. coli S6 under dark conditions, respectively (Fig. 4H). The culture was scaled up to a $3.6 \mathrm{~L}$ fermenter, and the starchbased shikimate titer and E. coli $\mathrm{S} 6$ productivity under light conditions increased to $50.96 \mathrm{~g} \mathrm{~L}^{-1}$ and $0.71 \mathrm{~g} \mathrm{~L}^{-1}$ $\mathrm{h}^{-1}$, which were $62.81 \%$ and $62.81 \%$ greater than those of E. coli S6 under dark conditions (Fig. 4I, J). Finally, the formation of biofilm-based SpyTag/SpyCatcher system of E. coli S1 and S6 under the light or dark condition were identified through TEM analysis (Fig. 4K).

\section{Enhancing L-malate production via increased CdS and NADH concentrations with an improved contact surface}

An engineered E. coli M1 was constructed in which the $c a, p c k$, and $m d h$ genes involved in the L-malate synthesis pathway were overexpressed, while the 
A

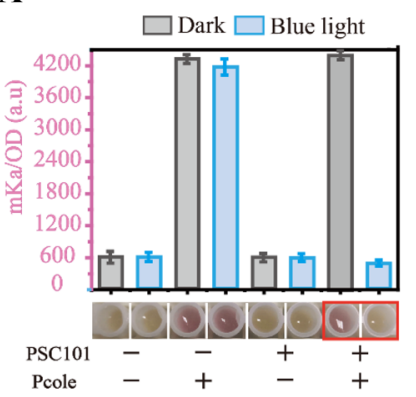

D

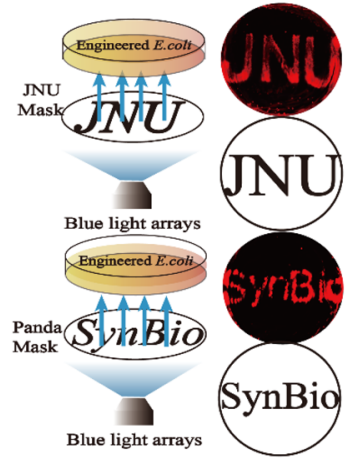

G
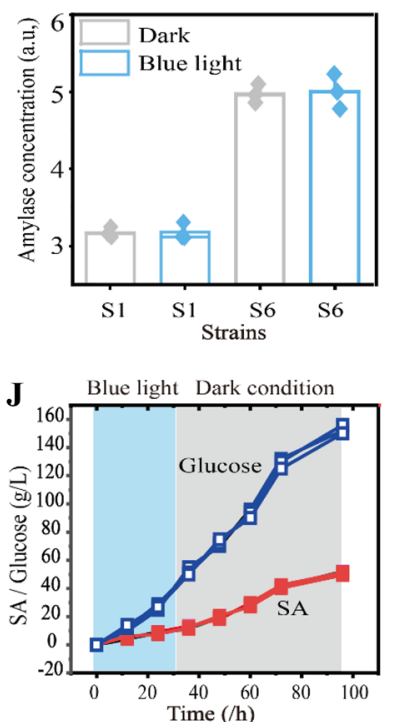

B



E

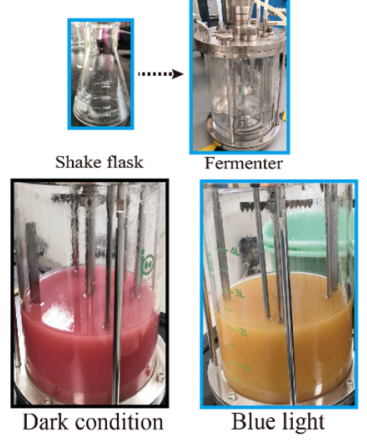

H

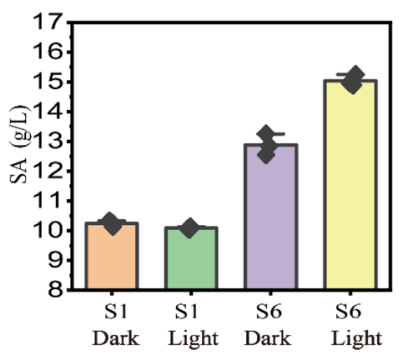

C
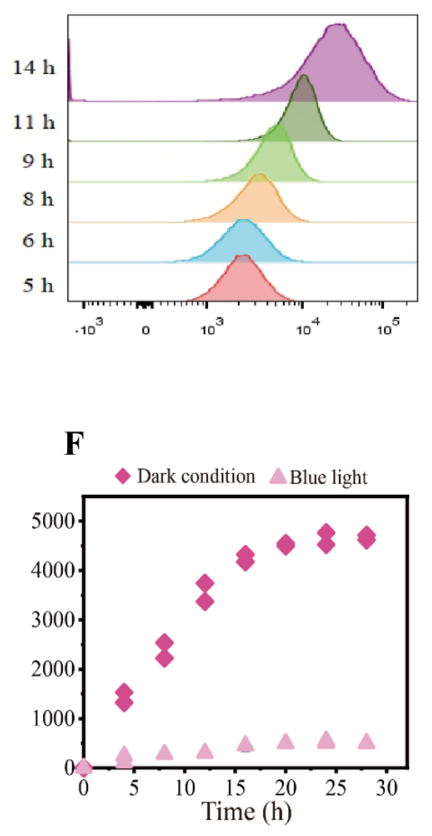

I

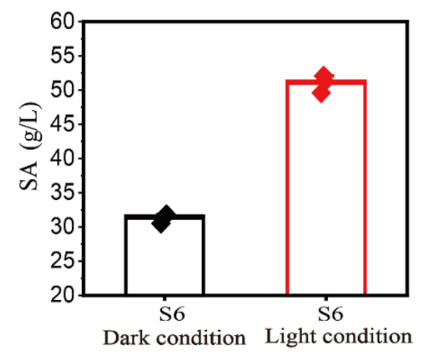

K

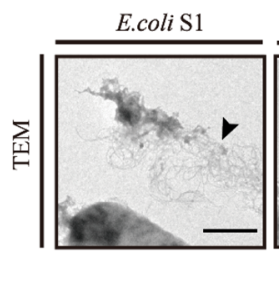

E.coli $\mathrm{S} 1+$ Light

E.coli $\mathrm{S} 6$

E.coli S6 + Light
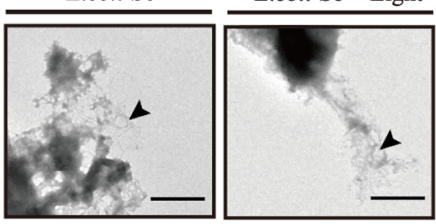

Fig. 4 Increasing shikimate production by biofilm self-assembly. A Fluorescence repression with BLRS under different conditions. B, C Fluorescence repression detection through Flow cytometer analysis under the different conditions. D Bioimage for "JNU" and "SynBio" was achieved through utilizing BLRS system. E The BLRS system scaled up to $5 \mathrm{~L}$ fermenter under the blue light and dark conditions. F The Fluorescence repression of BLRS system in the $5 \mathrm{~L}$ fermenter under the blue light and dark conditions. G Comparing the enzyme concentration with different strains. $\mathbf{H}$ Comparing the shikimate titer with different strains. I Shikimate production with $3.6 \mathrm{~L}$ fermenter by light stimulation during fed-batch fermentation with $E$. coli S6. J Shikimate production in the $3.6 \mathrm{~L}$ fermenter with two stage fermentation. $\mathbf{K}$ The formation of biofilm-based SpyTag/SpyCatcher system of $E$. coli S1 and S6 under the light or dark conditions. For A, G, H, I, n=3. For F, $n=2$. Error bars, mean \pm s.d. Scale bar for (K) is $1 \mu \mathrm{m}$,

key pathway enzyme MDH is a NADH-dependent enzymes (Hu et al. 2018)(Fig. 5A). Thus, the newly constructed CdS-biohybrid system was used for NADH regeneration by light irradiation, leading to E. coli M2 formation (Fig. 5A and Additional file 1: Figure S2). Then, NADH metabolism was analyzed in engineered 

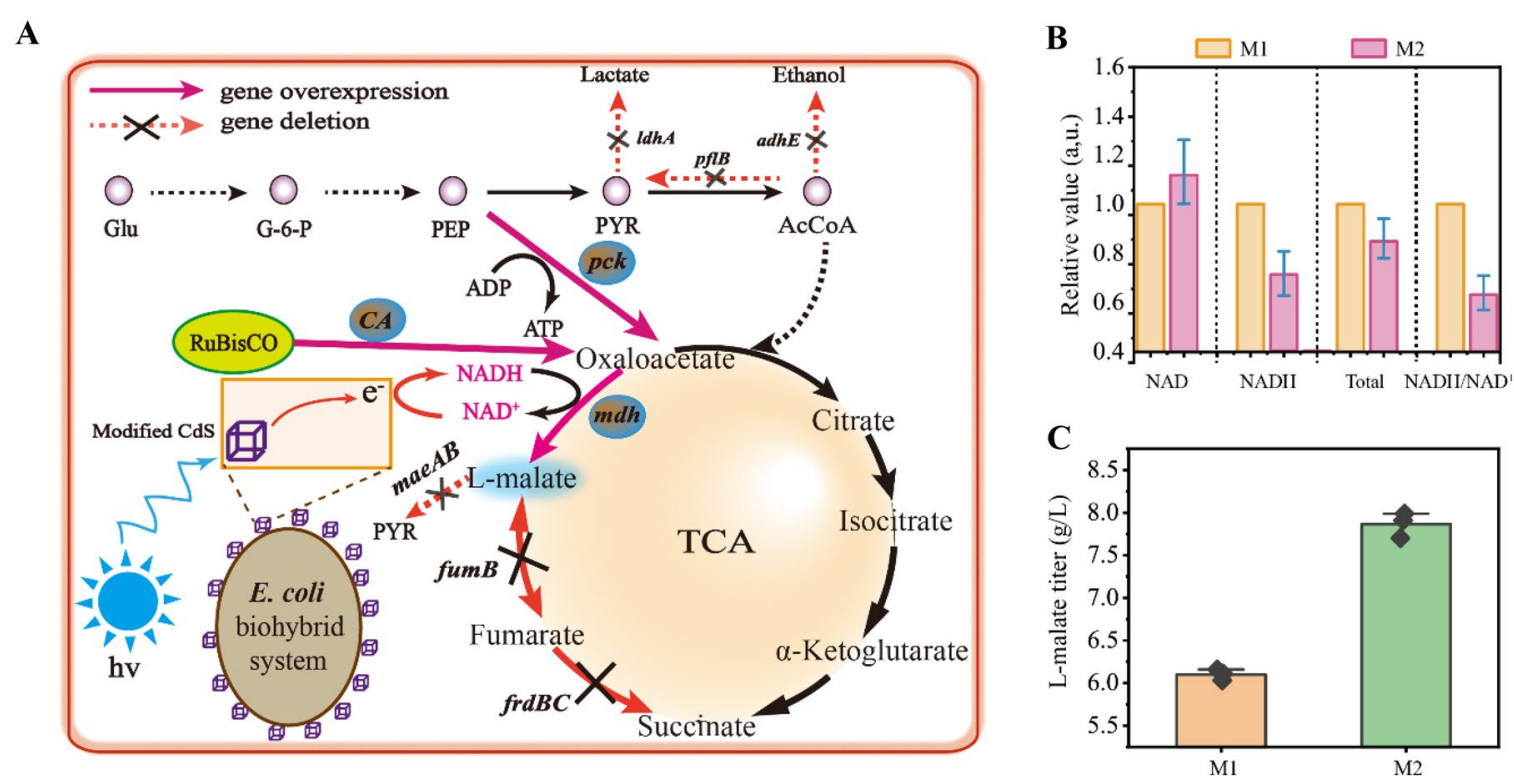

D

E

(i) Biofilm formation mode (ii) Malate production mode

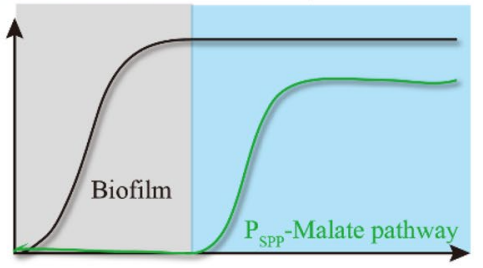

Modified biofilm

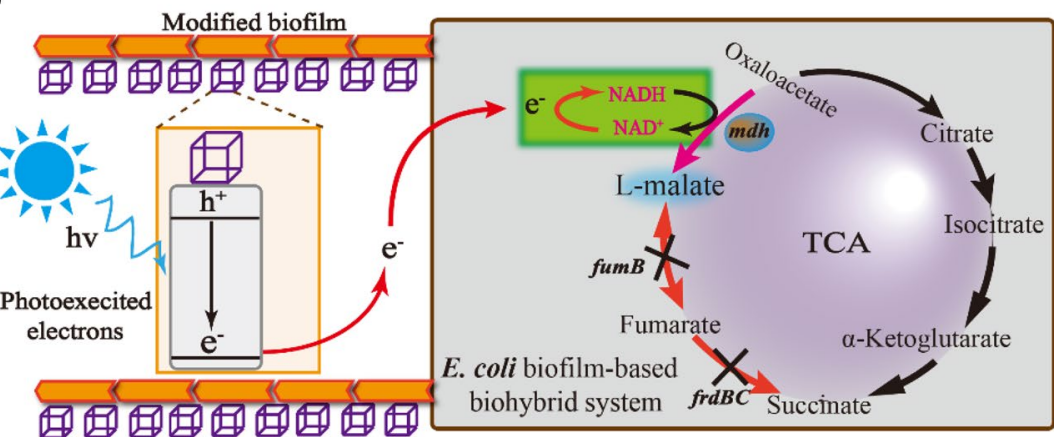

Fig. 5 Engineering L-malate biosynthesis by biofilm biohybrid system. A The schematic diagram of L-malate biosynthesis pathway in E. coli M1. B L-malate titer different strains with biofilm biohybrid system. C Biohybrids system for transporting electricity for NADH regeneration under blue light illumination. D Conceptual graph of two modes fermentation for shikimate production. E Conceptual graph of light-driven biofilm-based biohybrid system with $\mathrm{NADH}$ regeneration. For B, C, $n=3$. Error bars, mean \pm s.d. Each genes: PCK, phosphoenolpyruvate carboxykinase; MDH, L-malate dehydrogenase

E. coli M1 and M2. (1) The NADH concentration and $\mathrm{NADH} / \mathrm{NAD}^{+}$ratio of $E$. coli M2 were decreased by $32 \%$ and $39 \%$ compared to those of E. coli M1 (Fig. 5B). (2) The concentrations of $\mathrm{Cd}$ and $\mathrm{S}$ elements in E. coli M2 were only $110.2 \mu \mathrm{g} \mathrm{L}^{-1}$ and $295.3 \mu \mathrm{g} \mathrm{L} \mathrm{L}^{-1}$ in the biofilm-based biohybrid system (Fig. 2J). (3) The L-malate titer and E. coli M2 productivity increased to $7.77 \mathrm{~g}$ $\mathrm{L}^{-1}$ and $0.11 \mathrm{~g} \mathrm{~L}^{-1} \mathrm{~h}^{-1}$, showing $27.38 \%$ and $27.38 \%$ increases compared to those of E. coli M1, respectively (Fig. 5C). The decreased NADH concentration may limit L-malate production owing to a low concentration of CdS nanoparticles. To improve NADH regeneration during the L-malate fermentation process, a strategy was introduced to increase electron transfer by dividing the process of L-malate biosynthesis into two modes: (i) a biofilm formation mode, in which biofilm formation was increased by the constitutive expression of $\operatorname{csg} A$, and (ii) a L-malate production mode, in which pathway enzymes were expressed by stationary phase promoters and the biofilm-based CdS-biohybrid system under light irradiation (Fig. 6D, E).

To efficiently control these two modes, light-driven system was used to regulate the biofilm-based CdSbiohybrid system for NADH regeneration. Congo red can degraded with electron-hole pairs of biofilm-based CdS-biohybrid system, due to the hydroxyl radicals are generated by the flow of electrons (Jin et al. 2021). Thus, electron transfer in the biofilm-based CdS-biohybrid system under light irradiation was confirmed using a Congo red degradation assay, showing that Congo 
A

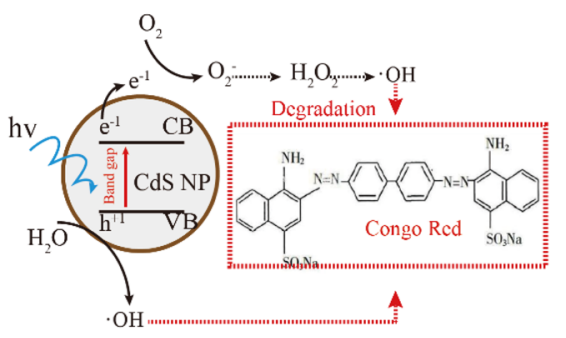

D

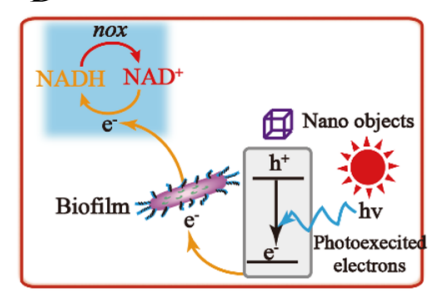

G

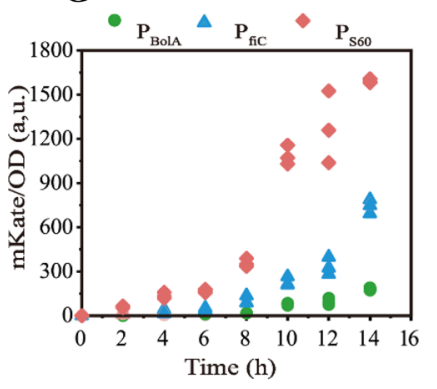

J

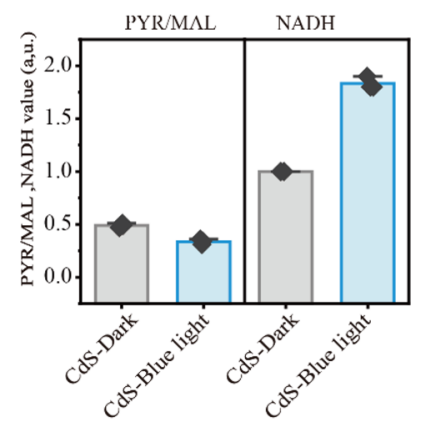

B

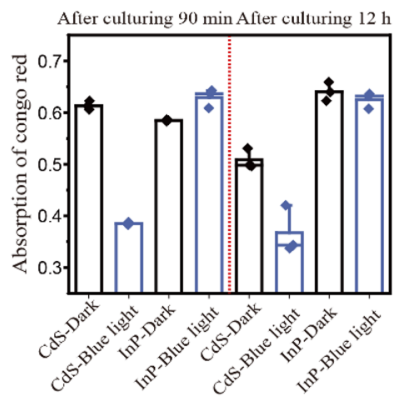

E

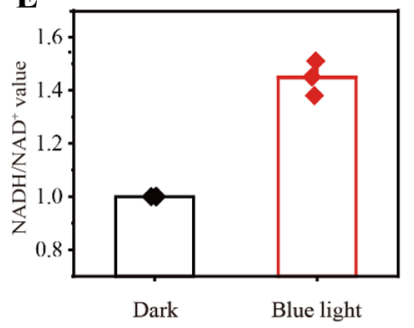

H

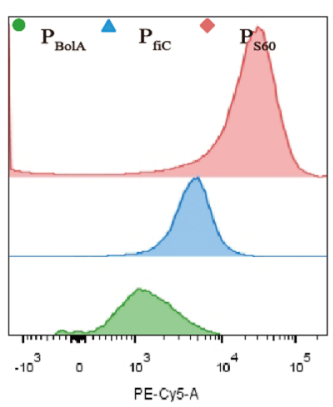

K

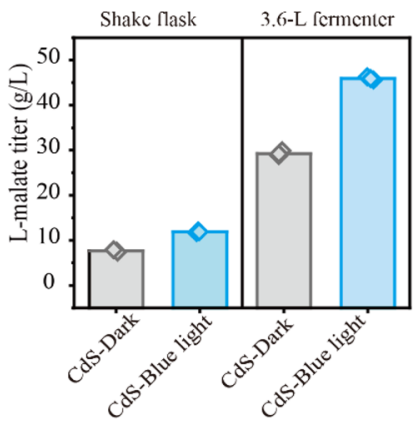

C

After culturing $90 \mathrm{~min}$

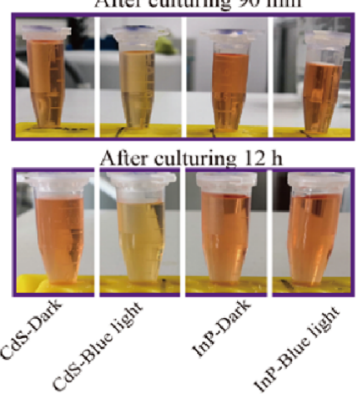

F
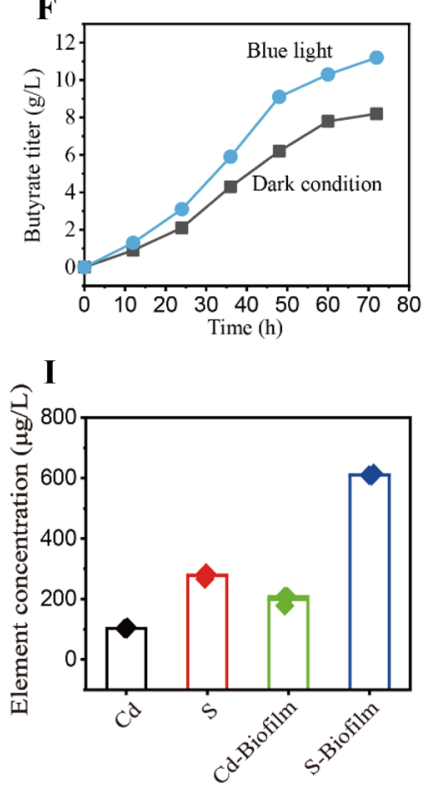

L

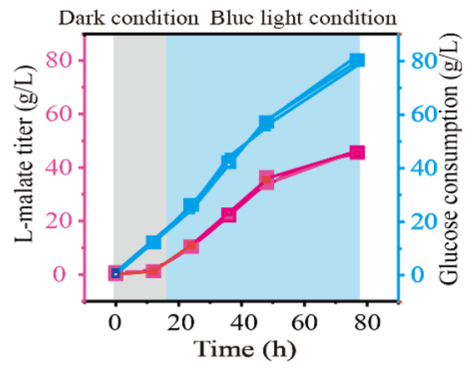

Fig. 6 Enhancing L-malate production by biofilm biohybrid system. A-C The congo red degradation assay with or without blue light irradiation in the CdS- or InP-biohybrid system. D, E NADH regeneration in NOX overexpressing strain under the dark or blue light conditions. F Butyrate titer with CdS-biohybrid system under the blue light or dark conditions. G Fluorescence activation with different stationary phase promoters. $\mathbf{H}$ Fluorescence activation with different stationary phase promoters through flow cytometer analysis. I Comparing the CdS nanoparticle concentration with different conditions. J Comparing the pyruvate/L-malate and NADH value with different conditions. $\mathbf{K} \mathrm{L}$-malate production with the engineered E. coli M6 controlled by light irradiation during $3.6 \mathrm{~L}$ fed-batch fermentation. $\mathbf{L}$ L-malate production in the $3.6 \mathrm{~L}$ fermenter with two-stage fermentation. For B, E-L, $n=3$

red was degraded by $37.26 \%$ after the assembly of $\mathrm{CdS}$ nanoparticles (Fig. 6A-C). The biofilm-based CdS-biohybrid system was introduced into $E$. coli M3 to express
NADH oxidase. Thus, the NADH concentration of $E$. coli M3 was $45.6 \%$ higher than that of the strain without the biofilm-based CdS-biohybrid system (Fig. 6D, 
E). Finally, the CdS-biohybrid system was introduced into NADH-dependent butyrate-producing strain, and the result showed that the butyrate titer and NADH value increased by $43 \%$ and $52 \%$, compared to that of dark condition (Fig. 6F and Additional file 1: Figure S11). Taken together, these results demonstrated that this biofilm-based CdS-biohybrid system can efficiently regenerate NADH for biomanufacturing.

The biofilm-based CdS-biohybrid system was introduced into $E$. coli M1 to increase the contact surface, resulting in the improvement of CdS and NADH concentrations for L-malate production under light irradiation. Different strengths of stationary phase promoters were analyzed via enzyme labeling and flow cytometer to control the expression of L-malate pathway enzymes (Fig. 6G, H). The two modes were established by manipulating the timing of light illumination and stationary phase promoters, respectively. Thus, different stationary phase promoters were combined with the biofilm-based CdS-biohybrid system to obtain E. coli M4, E. coli M5, and E. coli M6. The CdS and NADH concentrations of $E$. coli M6 under light conditions increased by $90.28 \%(\mathrm{Cd})$, $120.27 \%(\mathrm{~S})$, and $83.3 \%$, while the pyruvate/L-malate of E. coli M6 was $31 \%$ lower than that of E. coli M6 under dark conditions (Fig. 6I, J). This led to increases in the L-malate titer and E. coli M6 productivity under light conditions to $11.9 \mathrm{~g} \mathrm{~L}^{-1}$ and $0.16 \mathrm{~g} \mathrm{~L}^{-1} \mathrm{~h}^{-1}$, which were $55.96 \%$ and $55.96 \%$ higher than those of E. coli M6 under dark conditions (Fig. 6K). The culture was scaled up to a 3.6 $\mathrm{L}$ fermenter, and the L-malate titer and productivity of E. coli M6 under light conditions increased to $45.93 \mathrm{~g}$ $\mathrm{L}^{-1}$ and $0.59 \mathrm{~g} \mathrm{~L}^{-1} \mathrm{~h}^{-1}$, which were $56.76 \%$ and $56.76 \%$ greater than those of E. coli M6 under dark conditions (Fig. 6L).

\section{Discussion}

In this study, a biofilm-based SpyTag/SpyCatcher system and a CdS-biohybrid system were developed to improve the contact surface of $E$. coli strains for the production of starch-based shikimate and NADH-dependent L-malate, which integrate the optogenetics system, light-driven, and metabolic pathway. To this end, three strategies were adopted: (i) induction of the expression of the curli nanofiber gene $\operatorname{csg} A$, which promotes E. coli biofilm formation and possesses multiple functions; (ii) the development of a biofilm-based SpyTag/SpyCatcher protein system and biofilm-based CdS-biohybrid system to improve the contact surface; and (iii) the improvement of the contact surface to increase the amylase and CdS concentrations, thereby increasing the glucose and NADH concentrations and promoting starch-based shikimate and $\mathrm{NADH}$-dependent L-malate production.
Upon the implementation of these strategies, the titers of starch-based shikimate and NADH-dependent L-malate increased to $50.96 \mathrm{~g} \mathrm{~L}^{-1}$ and $45.93 \mathrm{~g} \mathrm{~L}^{-1}$, respectively.

In this article, through Congo red absorbance, fluorescence microscopy, and TEM, we observed that the contact surface was improved by the biofilm-based Spy$\mathrm{Tag} / \mathrm{SpyCatcher}$ protein system in which GFP was displayed around the E. coli surface or by the biofilm-based CdS-biohybrid system in which CdS nanoparticles were attached to the E. coli surface. The restricted contact surface limits the biomanufacturing process; therefore, the bioconversion efficiency can be improved by increasing the contact surface. Previous studies aimed at improving the contact surface have utilized various strategies. For example, glycosylphosphatidylinositol (GPI)-anchored cell wall proteins can attach to heterologous proteins on the cell surface to increase the contact surface between the enzyme and substrate (Inokuma et al. 2020). The cellulosome has been utilized to form a multi-enzyme complex structure on the cell wall to increase lignocellulose degradation (Tsai et al. 2010). Outer membrane proteins have been developed to display specific proteins on the cell surface to increase the contact surface with modified nanoparticles (Wei et al. 2018). The key metabolic pathway has been compartmentalized into natural or artificial organelles for improving the contact surface of enzymes and substrates to enhance the transformation of intermediates to targeted chemicals (Avalos et al. 2013; Reifenrath et al. 2020).

Finally, upon the improvement of the contact surface, the amylase and glucose concentrations increased by $48.57 \%$ and $20.07 \%$, leading to $62.81 \%$ and $62.81 \%$ improvements in the shikimate titer and productivity. The CdS and NADH concentrations were improved by $53.64 \%(\mathrm{~S}), 112.07 \%(\mathrm{Cd})$, and $83.3 \%$, resulting in $56.76 \%$ and $56.76 \%$ increases in the L-malate titer and productivity. On one hand, the low amylase concentration limits shikimate production based on starch as a substrate. Previous attempts to improve shikimate production have mainly focused on the following: knocking out $p g i$ of $E$. coli in KPM1 SA1/pKPM-SA1 to allow a greater NADPH for key enzymes in the shikimate synthesis pathway (Ahn et al. 2011); inactivating the phosphotransferase system gene ptsHIcrr, shikimate kinases I and II aroK and aroL, and pyruvate kinase I $p y k F$ to inhibit downstream gene expression and enhance the upstream carbon flux (Alberto 2011); overexpressing PTS and an endogenous myo-inositol transporter IolT1 and glucokinases to increase the key precursor for shikimate production (Kogure et al. 2016); and utilizing a glucose-xylose cosubstrate to decouple cell growth and shikimate synthesis (Fujiwara et al. 2020). On the other hand, NADH regeneration limits L-malate production. Previous studies to 
increase L-malate biosynthesis have mainly focused on the following: designing pyruvate carboxylation, oxaloacetate reduction, and L-malate transport systems in Saccharomyces cerevisiae to increase L-malate production (Zelle et al. 2008); using adaptive laboratory evolution and medium optimization in Ustilago trichophora TZ1 to achieve high cell density fermentation for L-malate biosynthesis (Zambanini et al. 2016); engineering S. cerevisiae for the transport of dicarboxylic acids by the SpMae1(p) transporter to increase L-malate production (Darbani et al. 2019); and displaying surface CdS nanoparticles on the E. coli cell membrane to absorb light energy for NADH regeneration in the NADH-dependent L-malate biosynthesis process (Hu et al. 2021b).

According to study of CdS-biohybrid system: (i) A surface-display biohybrid was constructed through CdS nanoparticle for improving the $\mathrm{H}_{2}$ production to $0.52 \pm 0.01 \mathrm{mmol} / 10^{8}$ cells (Wei et al. 2018). Similarly, the $\mathrm{CdS}$ nanoparticle for NADH regeneration with $\mathrm{CO}_{2} \mathrm{fix}$ (Hu et al. 2021a). (ii) The CdS was synthesized through addition of $\mathrm{Cd}^{2+}$ and cysteine was used to attach the electrotroph $M$. thermoacetica for acetate production (Sakimoto and Yang 2016). (iii) The CdS nanoparticle was used to attach the acetogenic Clostridium autoethanogenum for improving the $\mathrm{NADH} / \mathrm{NAD}^{+}$ratio (Jin et al. 2021). (iv) $\mathrm{Cd}\left(\mathrm{NO}_{3}\right)_{2}$ was used to form the $\mathrm{CdS}$ nanoparticle to attach the Clostridium beijerinckii for producing $10.24 \mathrm{~g} / \mathrm{L}$ butanol (Wang et al. 2021). As for using CdS-biohybrid system to improve the NADH: (i) Compared to gene expression for NADH regeneration, the CdS-biohybrid system was constructed to generate the NADH not only can decouple the L-malate production and NADH regeneration of endogenous metabolisms, but also can improve the L-malate production in a carbon and energy-efficient utilization way (Jin et al. 2021; Wei et al., 2018). In addition, it was easily to obtain and manipulate the CdS-biohybrid system (Guo et al., 2018; Sakimoto and Yang, 2016). (ii) In this study, the CdS nanoparticle was attached to $E$. coli biofilm through polyphenol-based method. Therefore, the Cd element and S element of CdS-biohybrid system were efficiently increased by $90.28 \%$ and $120.27 \%$, which was better than the natural absorption system. (iii) The NADH concentration of this CdS-biohybrid system was increased to $32 \mu \mathrm{mol} / \mathrm{gDCW}$, which showed an $83.3 \%$ improvement, compared to that of control. Furthermore, the L-malate titer and productivity of this CdS-biohybrid system were efficiently increased to $45.93 \mathrm{~g} / \mathrm{L}$ and $0.59 \mathrm{~g} / \mathrm{L} / \mathrm{h}$ with a lower metabolic burden, which were improved by $56.76 \%$ and $56.76 \%$.

Taken together, the biofilm-based regulation strategy provides a platform for improving the contact surface in a controlled spatiotemporal and reversible manner. The biofilm-based SpyTag/SpyCatcher protein system and biofilm-based CdS-biohybrid system not only improve the contact surface but also increase the glucose and $\mathrm{NADH}$ concentrations to increase targeted chemical production. This biofilm-based strategy is an attractive approach for the construction of microbial cell factories for high-value chemical production.

\section{Supplementary Information}

The online version contains supplementary material available at https://doi. org/10.1186/s40643-021-00470-7.

Additional file 1. Gene sequences used for plasmids and strains construction; Figures S1-S11 and Tables S1-S5 were set in the supporting information.

\section{Acknowledgements}

Not applicable.

\section{Authors' contributions}

$\mathrm{QD}, \mathrm{XLC}$, and $\mathrm{LML}$ conceived this project and designed the experiments. QD and YDL performed the experiments. LG, CG, JC, WC, and GPH provided technical assistance. XLC and LML provided overall project supervision. QD analyzed the data and wrote the manuscript. All the authors reviewed and approved the manuscript.

\section{Funding}

This work was supported by the National Key R \& D Program of China (2020YFA0908300), the Science Fund for Creative Research Groups of the National Natural Science Foundation of China (32021005), the Provincial Outstanding Youth Foundation of Jiangsu Province (BK20211529), the National Natural Science Foundation of China $(21978113,22008087)$, and the National Natural Science Foundation of China (22108099).

Availability of data and materials

All data generated or analyzed during this study are included in this article.

\section{Declarations}

Ethics approval and consent to participate

Not applicable.

\section{Consent for publication}

All the authors approved the consent for publishing the manuscript to bioresources and bioprocessing.

\section{Competing interests}

The authors declare that they have no competing interests.

\section{Author details}

${ }^{1}$ State Key Laboratory of Food Science and Technology, Jiangnan University, 1800 Lihu Road, Wuxi 214122, China. ${ }^{2}$ International Joint Laboratory On Food Safety, Jiangnan University, Wuxi 214122, China.

Received: 3 October 2021 Accepted: 22 November 2021

Published online: 30 November 2021

\section{References}

Ahn J, Chung BK, Lee DY, Park M, Karimi IA, Jung JK, Lee H (2011) NADPHdependent pgi-gene knockout Escherichia coli metabolism producing shikimate on different carbon sources. FEMS Microbiol Lett 324(1):10-16 Alberto RJLB, Noemí F, Georgina HC, Octavio TR, Guillermo G, Francisco B (2011) Constitutive expression of selected genes from the pentose 
phosphate and aromatic pathways increases the shikimic acid yield in high-glucose batch cultures of an Escherichia coli strain lacking PTS and pykF. Microb Cell Fact 12:86

Alper H, Stephanopoulos G (2007) Global transcription machinery engineering: a new approach for improving cellular phenotype. Metab Eng 9(3):258-267

Alvarez-Ordóez A, Coughlan LM, Briandet R, Cotter PD (2019) Biofilms in food processing environments: challenges and opportunities. Annu Rev Food SciT 10(1):173-195

Avalos JL, Fink GR, Stephanopoulos G (2013) Compartmentalization of metabolic pathways in yeast mitochondria improves the production of branched-chain alcohols. Nat Biotechnol 31(4):335-341

Benedetti I, de Lorenzo V, Nikel PI (2016) Genetic programming of catalytic Pseudomonas putida biofilms for boosting biodegradation of haloalkanes. Metab Eng 33:109-118

Castellana M, Wilson MZ, Xu Y, Joshi P, Cristea IM, Rabinowitz JD, Gitai Z, Wingreen NS (2014) Enzyme clustering accelerates processing of intermediates through metabolic channeling. Nat Biotechnol 32(10):1011-1018

Choe D, Lee JH, Yoo M, Hwang S, Sung BH, Cho S, Palsson B, Kim SC, Cho B-K (2019) Adaptive laboratory evolution of a genome-reduced Escherichia coli. Nat Commun 10(1):1-14

Choi KR, Jang WD, Yang D, Cho JS, Park D, Lee SY (2019) Systems metabolic engineering strategies: integrating systems and synthetic biology with metabolic engineering. Trends Biotechnol 37(8):817-837

Cuny L, Pfaff D, Luther J, Ranzinger F, Hille-Eichel A (2019) Evaluation of productive biofilms for continuous lactic acid production. Biotechnol Bioeng 116(14):2687-2697

Darbani B, Stovicek V, van der Hoek SA, Borodina I (2019) Engineering energetically efficient transport of dicarboxylic acids in yeast Saccharomyces cerevisiae. Proc Natl Acad Sci USA 116(39):19415-19420

DeLoache WC, Russ ZN, Dueber JE (2016) Towards repurposing the yeast peroxisome for compartmentalizing heterologous metabolic pathways. Nat Commun 7:11152

Ding Q, Diao W, Gao C, Chen X, Liu L (2020) Microbial cell engineering to improve cellular synthetic capacity. Biotechnol Adv 45:107649

Dueber JE, Wu GC, Malmirchegini GR, Moon TS, Petzold CJ, Ullal AV, Prather KL, Keasling JD (2009) Synthetic protein scaffolds provide modular control over metabolic flux. Nat Biotechnol 27(8):753-759

Ellis GA, Klein WP, Lasarte-Aragonés G, Thakur M, Walper SA, Medintz IL (2019) Artificial multienzyme scaffolds: pursuing in vitro substrate channeling with an overview of current progress. ACS Catal 9(12):10812-10869

Ercan D, Demirci A (2013) Current and future trends for biofilm reactors for fermentation processes. Crit Rev Biotechnol 35(1):1-14

Fujiwara R, Noda S, Tanaka T, Kondo A (2020) Metabolic engineering of Escherichia coli for shikimate pathway derivative production from glucosexylose co-substrate. Nat Commun 11(1):279

Gilbert C, Ellis T (2019) Biological engineered living materials: Growing functional materials with genetically programmable properties. ACS Synth Biol 8(1):1-15

Grewal PS, Samson JA, Baker JJ, Choi B, Dueber JE (2020) Peroxisome compartmentalization of a toxic enzyme improves alkaloid production. Nat Chem Biol 17:96-103

Guo JL, Suástegui M, Sakimoto KK, Moody VM, Xiao G, Nocera DG, Joshi NS (2018) Light-driven fine chemical production in yeast biohybrids. Science 25(10):158-169

Hammer SK, Avalos JL (2017) Harnessing yeast organelles for metabolic engineering. Nat Chem Biol 13(8):823-832

Honjo H, Iwasaki K, Soma Y, Tsuruno K, Hamada H, Hanai T (2019) Synthetic microbial consortium with specific roles designated by genetic circuits for cooperative chemical production. Metab Eng 55:268-275

Hu GP, Zhou J, Chen XL, Qian YY, Gao C, Guo L, Xu P, Chen W, Chen J, Li Y, Liu LM (2018) Engineering synergetic $\mathrm{CO}_{2}$-fixing pathways for malate production. Metab Eng 47:496-504

Hu GP, Li Z, Ma DL, Ye C, Zhang LP, Gao C, Liu LM, Chen XL (2021a) Light-driven $\mathrm{CO}_{2}$ sequestration in Escherichia coli to achieve theoretical yield of chemicals. Nat Catal 4:395-406

Hu GP, Li ZH, Ma DL, Ye C, Zhang LP, Gao C, Liu LM, Chen XL (2021 b) Lightdriven $\mathrm{CO} 2$ sequestration in Escherichia coli to achieve theoretical yield of chemicals. Nat Catal 4:395-406
Huang J, Liu S, Zhang C, Wang X, Pu J, Ba F, Xue S, Ye H, Zhao T, Li K et al (2019) Programmable and printable Bacillus subtilis biofilms as engineered living materials. Nat Chem Biol 15(1):34-41

Inokuma K, Kurono H, Haan RD, Heber van Zyl W, Hasunuma T, Kondo A (2020) Novel strategy for anchorage position control of GPI-attached proteins in the yeast cell wall using different GPI-anchoring domains. Metab Eng 57:110-117

Jayaraman P, Devarajan K, Chua TK, Zhang H, Gunawan E, Poh CL (2016) Blue light-mediated transcriptional activation and repression of gene expression in bacteria. Nucleic Acids Res 44(14):6994-7005

Jayaraman P, Yeoh JW, Zhang J, Poh CL (2018) Programming the dynamic control of bacterial gene expression with a chimeric ligand- and light-based promoter system. ACS Synth Biol 7(11):2627-2639

Jiang L, Song X, Li Y, Xu Q, Pu J, Huang H, Zhong C (2018) Programming integrative extracellular and intracellular biocatalysis for rapid, robust, and recyclable synthesis of trehalose. ACS Catal 8(3):1837-1842

Jiang Y, Liu Y, Zhang X, Gao H, Mou L, Wu M, Zhang W, Xin F, Jiang M (2021) Biofilm application in the microbial biochemicals production process. Biotechnol Adv 48:107724

Jin S, Jeon Y, Jeon MS, Shin J, Song Y, Kang S, Bae J, Cho S, Lee JK, Kim DR et al (2021) Acetogenic bacteria utilize light-driven electrons as an energy source for autotrophic growth. Proc Natl Acad Sci U S A 118(9):e2020552118

Kay E, Humair B, Denervaud V, Riedel K, Spahr S, Eberl L, Valverde C, Haas D (2006) Two GacA-dependent small RNAs modulate the quorum-sensing response in Pseudomonas aeruginosa. J Bacteriol 188(16):6026-6033

Knop DR, Chandran SS, Barker JL, von Daeniken R, Weber W, Frost JW (2001) Hydroaromatic equilibration during biosynthesis of shikimic acid. J Am Chem Soc 123:10173-10182

Ko YS, Kim JW, Lee JA, Han T, Kim GB, Park JE, Lee SY (2020) Tools and strategies of systems metabolic engineering for the development of microbial cell factories for chemical production. Chem Soc Rev 49(14):4615-4636

Kogure T, Kubota T, Suda M, Hiraga K, Inui M (2016) Metabolic engineering of Corynebacterium glutamicum for shikimate overproduction by growtharrested cell reaction. Metab Eng 38:204-216

Koizumi S, Endo T, Tabata K, Ozaki A (1998) Large-scale production of UDPgalactose and globotriose by coupling metabolically engineered bacteria. Nat Biotechnol 16(9):847-850

Kuska J, O'Reilly E (2020) Engineered biosynthetic pathways and biocatalytic cascades for sustainable synthesis. Curr Opin Chem Biol 58:146-154

Lee SY, Kim HU (2015) Systems strategies for developing industrial microbial strains. Nat Biotechnol 33(10):1061-1072

Leonov PS, Flores-Alsina X, Gernaey KV, Sternberg C (2021) Microbial biofilms in biorefinery - towards a sustainable production of low-value bulk chemicals and fuels. Biotechnol Adv 50:107766

Li C, Zhang R, Wang J, Wilson LM, Yan Y (2020) Protein engineering for improving and diversifying natural product biosynthesis. Trends Biotechnol 38(7):729-744

Nguyen PQ, Botyanszki Z, Tay PK, Joshi NS (2014) Programmable biofilm-based materials from engineered curli nanofibres. Nat Commun 5(2):486-495

Nielsen J, Keasling JD (2016) Engineering cellular metabolism. Cell 164(6):1185-1197

Niemeyer CM, Sano T, Smith CL, Cantor CR (1994) Oligonucleotide-directed self-assembly of proteins: semisynthetic DNA-streptavidin hybrid molecules as connectors for the generation of macroscopic arrays and the construction of supramolecular bioconjugates. Nucleic Acids Res 22(25):5530-5539

Ohta K, BeallL DS, Mejia JP, Shanmugam KT, Ingram LO (1991) Genetic improvement of Escherichia coli for ethanol production: chromosomal integration of Zymomonas mobilis genes encoding pyruvate decarboxylase and alcohol dehydrogenase II. Appl Environ Microbiol 57(7):893-900

Olmez TT, Sahin Kehribar E, Isilak ME, Lu TK, Seker UOS (2019) Synthetic genetic circuits for self-actuated cellular nanomaterial fabrication devices. ACS Synth Biol 8(9):2152-2162

Pham HL, Wong A, Chua N, Teo WS, Yew WS, Chang MW (2017) Engineering a riboswitch-based genetic platform for the self-directed evolution of acidtolerant phenotypes. Nat Commun 8(1):411-423

Quijano-Rubio A, Yeh HW, Park J, Lee H, Langan RA, Boyken SE, Lajoie MJ, Cao L, Chow CM, Miranda MC et al (2021) De novo design of modular and tunable protein biosensors. Nature 591:482-487 
Reifenrath M, Oreb M, Boles E, Tripp J (2020) Artificial ER-derived vesicles as synthetic organelles for in Vivo compartmentalization of biochemical pathways. ACS Synth Biol 9(11):2909-2916

Sakimoto KKWAB, Yang P (2016) Self-photosensitization of nonphotosynthetic bacteria for solar-to-chemical production. Science 20(15-20):74-77

Sandoval NR, Papoutsakis ET (2016) Engineering membrane and cell-wall programs for tolerance to toxic chemicals: Beyond solo genes. Curr Opin Microbiol 33:56-66

Titorenko VI, Nicaud JM, Wang H, Chan H, Rachubinski RA (2002) Acyl-CoA oxidase is imported as a heteropentameric, cofactor-containing complex into peroxisomes of Yarrowia lipolytica. J Cell Biol 156(3):481-494

Tsai SL, Goyal G, Chen W (2010) Surface display of a functional minicellulosome by intracellular complementation using a synthetic yeast consortium and its application to cellulose hydrolysis and ethanol production. Appl Environ Microbiol 76(22):7514-7520

Valentini M, Filloux A (2016) Biofilms and cyclic di-GMP (c-di-GMP) signaling: Lessons from Pseudomonas aeruginosa and other bacteria. J Biol Chem 291(24):12547-12555

Walker KA, Atkins CL, Osuna R (1999) Functional determinants of the Escherichia coli fis promoter: Roles of $-35,-10$, and transcription initiation regions in the response to stringent control and growth phase-dependent regulation. J Bacteriol 181(4):1269-1280

Wang X, Li J, Zhang C, Zhang Y, Meng J (2021) Self-assembly of CdS@C. Beijerinckii hybrid system for efficient lignocellulosic butanol production. Chem Eng J 424(7144):130458

Wei W, Sun P, Li Z, Song K, Su W, Wang B, Liu Y, Zhao J (2018) A surface-display biohybrid approach to light-driven hydrogen production in air. Sci Adv 4(2):263-272

Yang D, Park SY, Lee SY (2021) Production of rainbow colorants by metabolically engineered Escherichia coli. Adv Sci 8:e2100743

Yarwood JM, Bartels DJ, Volper EM, Greenberg EP (2004) Quorum sensing in Staphylococcus aureus biofilms. J Bacteriol 186(6):1838-1850

Zambanini T, Kleineberg W, Sarikaya E, Buescher JM, Meurer G, Wierckx N, Blank LM (2016) Enhanced malic acid production from glycerol with high-cell density Ustilago trichophora TZ1 cultivations. Biotechnol Biofuels 9:135

Zelle RM, de Hulster E, van Winden WA, de Waard P, Dijkema C, Winkler AA, Geertman JM, van Dijken JP, Pronk JT, van Maris AJ (2008) Malic acid production by Saccharomyces cerevisiae: engineering of pyruvate carboxylation, oxaloacetate reduction, and malate export. Appl Environ Microbiol 74(9):2766-2777

Zhang GQ, Quin MB, Schmidt-Dannert C (2018) Self-assembling protein scaffold system for easy in vitro coimmobilization of biocatalytic cascade enzymes. ACS Catal 8(6):5611-5620

Zhao EM, Suek N, Wilson MZ, Dine E, Pannucci NL, Gitai Z, Avalos JL, Toettcher JE (2019) Light-based control of metabolic flux through assembly of synthetic organelles. Nat Chem Biol 15(6):589-597

\section{Publisher's Note}

Springer Nature remains neutral with regard to jurisdictional claims in published maps and institutional affiliations.

\section{Submit your manuscript to a SpringerOpen ${ }^{\circ}$ journal and benefit from:}

- Convenient online submission

- Rigorous peer review

- Open access: articles freely available online

- High visibility within the field

- Retaining the copyright to your article

Submit your next manuscript at $\mathbf{s p r i n g e r o p e n . c o m ~}$ 